\title{
HIV gp120 Protein Increases the Function of Connexin 43 Hemichannels and Pannexin-1 Channels in Astrocytes: Repercussions on Astroglial Function
}

\author{
Rosario Gajardo-Gómez ${ }^{1}$, Cristian A. Santibañez ${ }^{1}$, Valeria C. Labra ${ }^{1}$, Gonzalo I. Gómez ${ }^{2} \mathbb{E}$, \\ Eliseo A. Eugenin ${ }^{3}$ and Juan A. Orellana ${ }^{1, *(D)}$ \\ 1 Departamento de Neurología, Escuela de Medicina and Centro Interdisciplinario de Neurociencias, \\ Facultad de Medicina, Pontificia Universidad Católica de Chile, Santiago 8330024, Chile; \\ rgajardo1@uc.cl (R.G.-G.); c.santibanezahumada@gmail.com (C.A.S.); valelabra@gmail.com (V.C.L.) \\ 2 Institute of Biomedical Sciences, Faculty of Health Sciences, Universidad Autónoma de Chile, \\ Santiago 8910060, Chile; gonzalo.gomez@uautonoma.cl \\ 3 Department of Neuroscience, Cell Biology, and Anatomy, University of Texas Medical Branch, (UTMB), \\ Galveston, TX 77555, USA; eleugeni@utmb.edu \\ * Correspondence: jaorella@uc.cl; Tel.: +56-968399128
}

Received: 9 March 2020; Accepted: 27 March 2020; Published: 3 April 2020

\begin{abstract}
At least half of human immunodeficiency virus (HIV)-infected individuals suffer from a wide range of cognitive, behavioral and motor deficits, collectively known as HIV-associated neurocognitive disorders (HAND). The molecular mechanisms that amplify damage within the brain of HIV-infected individuals are unknown. Recently, we described that HIV augments the opening of connexin-43 (Cx43) hemichannels in cultured human astrocytes, which result in the collapse of neuronal processes. Whether HIV soluble viral proteins such as gp120, can regulate hemichannel opening in astrocytes is still ignored. These channels communicate the cytosol with the extracellular space during pathological conditions. We found that gp120 enhances the function of both Cx43 hemichannels and pannexin- 1 channels in mouse cortical astrocytes. These effects depended on the activation of IL-1 $\beta / T N F-\alpha$, p38 MAP kinase, iNOS, cytoplasmic $\mathrm{Ca}^{2+}$ and purinergic signaling. The gp120-induced channel opening resulted in alterations in $\mathrm{Ca}^{2+}$ dynamics, nitric oxide production and ATP release. Although the channel opening evoked by gp120 in astrocytes was reproduced in ex vivo brain preparations, these responses were heterogeneous depending on the CA1 region analyzed. We speculate that soluble gp120-induced activation of astroglial Cx43 hemichannels and pannexin-1 channels could be crucial for the pathogenesis of HAND.
\end{abstract}

Keywords: Cx43 hemichannels; connexins; gp120; glia; HIV; astrocyte

\section{Introduction}

After primary peripheral infection, the human immunodeficiency virus (HIV) crosses the blood-brain barrier (BBB) using monocytes as a vehicle, gaining access to the central nervous system (CNS) [1,2]. After that, the HIV infects both microglia and a small population of astrocytes [3,4], adversely affecting proper glial cell function and concomitant survival of neighboring neurons $[5,6]$. The latter has been linked to the release of proinflammatory cytokines and free radicals, cytoplasmic $\mathrm{Ca}^{2+}$ imbalance and glutamate excitotoxicity [5,6]. In parallel, infected glial cells release soluble viral proteins into the brain parenchyma, triggering direct neuronal toxicity $[7,8]$. Overall these mechanisms are thought to contribute to a wide range of cognitive, behavioral and motor deficits, collectively known as HIV-associated neurocognitive disorders (HAND) $[9,10]$. Despite that antiretroviral therapy has diminished the severity of HIV cognitive disorders, the prevalence of HAND in HIV-infected 
patients remains high $(50 \%)$ as they live longer and due to the relatively poor BBB penetrance of most antiretroviral drugs [11-14]. The prominent CNS damage observed in HIV-infected individuals with effective antiretroviral therapy had led to the thought that additional and novel mechanisms of bystander cell death might be implicated.

Embedded in the synaptic cleft, astrocytes govern crucial brain processes that include synaptic function and plasticity, energy supply for neurons, cytoplasmic $\mathrm{Ca}^{2+}$ signaling and homeostatic equilibrium of extracellular $\mathrm{pH}$, neurotransmitters and ions, along with controlling the redox and inflammatory response [15-18]. Previous studies have shown that HIV itself or the HIV gp120, the surface glycoprotein responsible for viral entry, impairs astroglial function with particularly detrimental consequences for neuronal survival $[19,20]$. Indeed, in astrocytes HIV gp120 alters the exchange of $\mathrm{Na}^{+} / \mathrm{H}^{+}$and glutamate efflux [21,22]; the levels of cytoplasmic $\mathrm{Ca}^{2+}[23]$ and the production of proinflammatory cytokines/chemokines and free radicals [24-26]. Despite the continuous ongoing research in the field, currently, there is no effective treatment for HAND and the precise underlying mechanism behind the pathological action of HIV and/or HIV gp120 remains not well understood.

A growing body of evidence has pointed out that cellular signaling mediated by hemichannels and pannexons might contribute to the dysfunction of astrocytes, with potentially significant repercussions for neuronal function and survival [27]. Hemichannels are plasma membrane channels containing six connexin subunits that oligomerize around a central pore, allowing autocrine/paracrine signaling via the exchange of ions and small molecules between the cytoplasm and the extracellular space [28]. Pannexins channels-also called pannexons-result from the oligomerization of pannexins, a three-member family of proteins with similar secondary and tertiary structures than connexins that establish plasma membrane channels permeable to ions and small molecules [29]. In pathological scenarios, instead of being beneficial, the persistent function of hemichannels and pannexons contributes to cell damage and dysfunction through different mechanisms, such as the release of potentially toxic molecules, intracellular $\mathrm{Ca}^{2+}$ imbalance and transmembrane ionic/osmotic disturbances [30,31]. In a prior study, we showed that HIV increases the opening of hemichannels but not pannexin channels in cultured human astrocytes, which result in the collapse of neuronal processes [32]. However, whether HIV derived viral proteins, including gp120, regulate hemichannel and/or pannexon opening in astrocytes is still unknown.

\section{Results}

\subsection{HIV gp120 Protein Increases the Function of Cx43 Hemichannels and Panx1 Channels in Cultured Astrocytes}

Given that the entire HIV virion induces the opening of Cx43 hemichannels in astrocytes [32], we examined whether the HIV envelope glycoprotein gp120 could affect the function of these channels in primary cortical astrocytes. The functional state of hemichannels was studied by recording the rate of ethidium (Etd) uptake. This fluorescent probe crosses the plasma cell membrane by diffusing through channels with large pores such as hemichannels [33]. In these experiments, gp120 caused a significant bell-shaped increase in astrocyte Etd uptake that peaked a 2.3-fold increase following $24 \mathrm{~h}$ of treatment and gradually declined over the days (Figure 1A-E). Furthermore, the stimulus for $24 \mathrm{~h}$ with gp120 was also bell-shaped depending on its concentration and reaching the highest value with $10 \mathrm{ng} / \mathrm{mL}$ treatment (Figure 1A,B). Thus, this concentration and time of treatment were used in all further experiments.

Since Cx43 hemichannels and Panx1 channels represent one of the most prevalent routes for dye influx in astrocytes [34,35], the potential contribution of these channels in the gp120-induced astroglial Etd uptake was examined. Accordingly, astrocyte cultures were preincubated for $15 \mathrm{~min}$ before and throughout Etd uptake recordings with various pharmacological agents. Tat-L2 $(100 \mu \mathrm{M})$ or gap19 $(100 \mu \mathrm{M})$; two inhibitory mimetic peptides with sequences equivalent to intracellular L2 loop regions of Cx43 [36-38]; completely blunted the gp120-induced Etd uptake in astrocytes to control values (Figure 1E,F). On the contrary, a mutated Tat-L2 (Tat-L2 ${ }^{\mathrm{H} 126 \mathrm{~K} / \mathrm{I130N}}$ ), in which two amino acids essential 
for the interaction of the L2 region with the carboxyl tail of Cx43 were modified, did not evoke a similar inhibitory response (Figure 1F). An equivalent unsuccessful suppression was observed with an inactive form of gap19 containing the I130A variation (gap191130A; Figure 1F). To further explore the implication of Panx1 channels in the gp120-induced Etd uptake in astrocytes, we used the mimetic peptide ${ }^{10}$ panx 1 with an amino acid sequence complementary to the first extracellular loop region of Panx1 [39] and probenecid, a potent inhibitor of these channels [40]. Both ${ }^{10}$ panx1 (100 $\left.\mu \mathrm{M}\right)$ and probenecid $(500 \mu \mathrm{M})$ elicited a substantial inhibitory influence on the Etd uptake triggered by gp120 in astrocytes (Figure 1F). Overall, these results reveal that gp120 boosts the function of Cx43 hemichannels and Panx1 channels in cultured astrocytes.
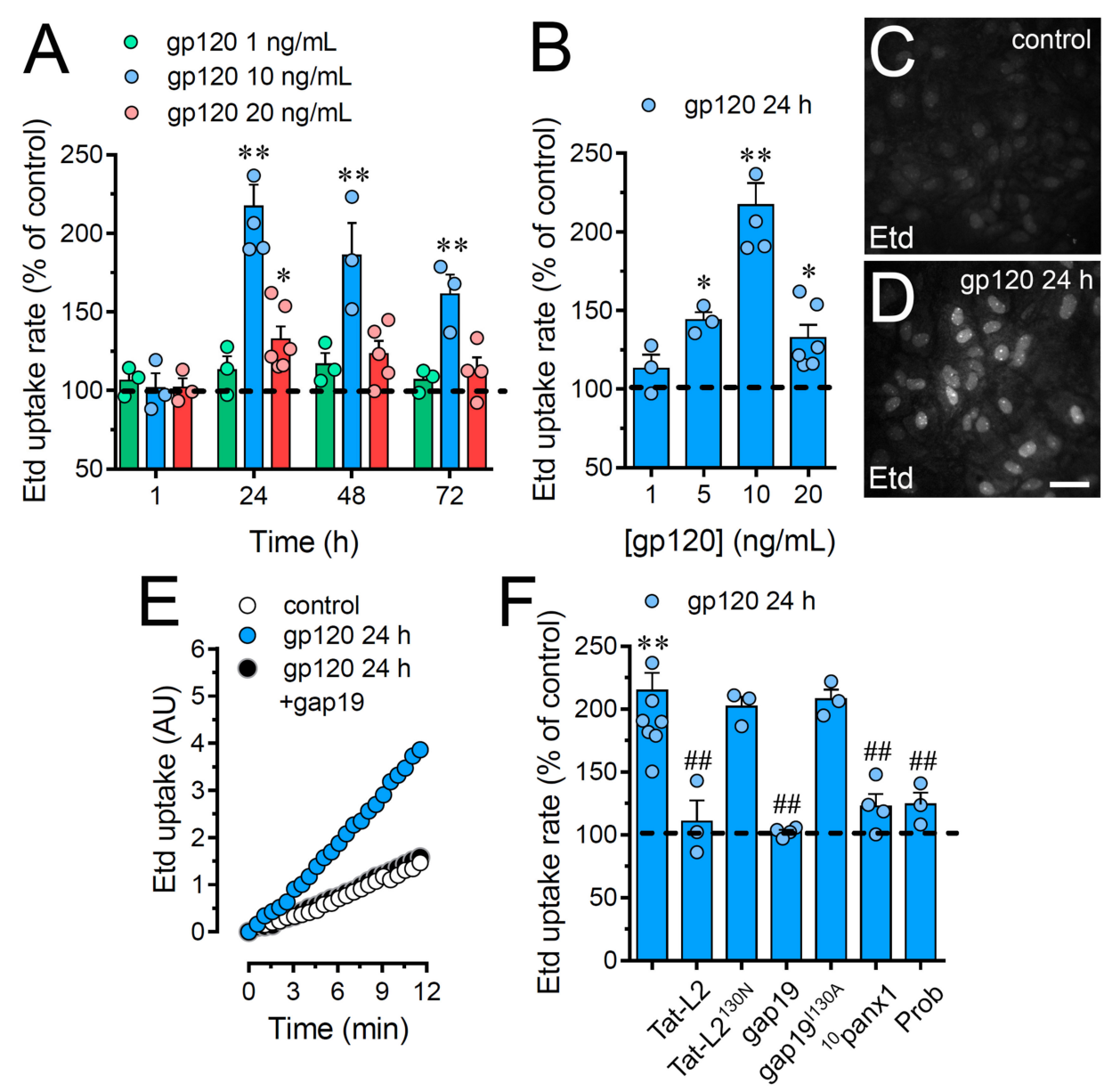

Figure 1. gp120 increases the function of Cx43 hemichannels and Panx1 channels in astrocytes. (A) Etd uptake rate normalized to control (dashed line) by astrocytes stimulated for distinct periods with gp120 at different concentrations: $1 \mathrm{ng} / \mathrm{mL}$ (green circles), $10 \mathrm{ng} / \mathrm{mL}$ (blue circles) or $20 \mathrm{ng} / \mathrm{mL}$ (red circles). ${ }^{*} p<0.05,{ }^{* *} p<0.01$, gp120 vs. control. (B) Etd uptake rate normalized to control (dashed line) by astrocytes stimulated for $24 \mathrm{~h}$ with distinct concentrations of gp120 (blue circles). ${ }^{*} p<0.05,{ }^{* *} p<0.01$, gp120 vs. control. (C,D) Etd staining from dye uptake measurements (10 min exposure to Etd) in astrocytes under control conditions (C) or stimulated for $24 \mathrm{~h}$ with $10 \mathrm{ng} / \mathrm{mL}$ gp120 (D). (E) Time-lapse recordings of Etd uptake by astrocytes under control conditions (white circles) or stimulated for $24 \mathrm{~h}$ with $10 \mathrm{ng} / \mathrm{mL}$ gp120 alone (blue circles) or plus $100 \mu \mathrm{M}$ gap19 (black circles). (F) Etd uptake rate normalized to control (dashed line) by astrocytes stimulated for $24 \mathrm{~h}$ with $10 \mathrm{ng} / \mathrm{mL}$ gp120 alone or plus the following blockers: $100 \mu \mathrm{M}$ Tat-L2, $100 \mu \mathrm{M}$ Tat-L2 ${ }^{\mathrm{H} 126 \mathrm{~K} / 1130 \mathrm{~N}}, 100 \mu \mathrm{M}$ gap19, $100 \mu \mathrm{M}$ gap19I130A , $100 \mu \mathrm{M}{ }^{10}$ panx1 or $500 \mu \mathrm{M}$ Probenecid (Prob). ${ }^{* *} p<0.01$, gp120 vs. control; \# $p<0.05$, \#\# $p<0.01$; pharmacological agents vs. gp120. Data were obtained from at least three independent experiments (see scatter dot plot) with three or more repeats each one ( $\geq 30$ cells analyzed for each repeat). Calibration bar $=45 \mu \mathrm{m}$. 


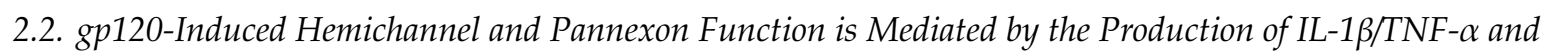

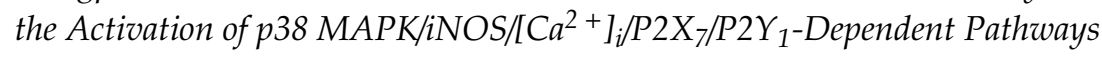

Prior evidence has described that the activation of astroglial hemichannels and pannexons during pathological conditions involves TNF- $\alpha / \mathrm{IL}-1 \beta$, p38 MAPK, inducible NO synthase (iNOS), $\mathrm{P} 2 \mathrm{X}_{7} / \mathrm{P}^{2} \mathrm{Y}_{1}$ receptors and cytoplasmic $\mathrm{Ca}^{2+}$ [41-44]. Consequently, we scrutinized the impact of these pathways in the gp120-induced Cx43 hemichannel and Panx1 channel function in astrocytes. The stimulation with sTNF-aR1 or IL-1ra, a soluble form of TNF- $\alpha$ receptor that binds TNF-or a recombinant antagonist for the IL-1 $\beta$ receptor, respectively, totally blunted the Etd uptake produced by $24 \mathrm{~h}$ of treatment with gp120 (Figure 2). Of note, the gp120-dependent Etd uptake was drastically suppressed by a blockade of p38 MAPK with $10 \mu \mathrm{M}$ SB202190, whereas L-N6 $(5 \mu \mathrm{M})$, an iNOS inhibitor, triggered a partial counteracting action (Figure 2). Given that rise in intracellular free $\mathrm{Ca}^{2+}$ concentration $\left(\left[\mathrm{Ca}^{2+}\right]_{\mathrm{i}}\right)$ and purinergic signaling are broadly known mechanisms that increase the function of $\mathrm{Cx} 43$ hemichannels and Panx1 channels $[42,45,46]$, we investigated if they were linked to the gp120-induced Etd uptake in astrocytes. Notably, chelation of $\left[\mathrm{Ca}^{2+}\right]_{\mathrm{i}}$ with $5 \mu \mathrm{M}$ BAPTA-AM, $200 \mu \mathrm{M}$ oATP (wide-spectrum P2X receptor

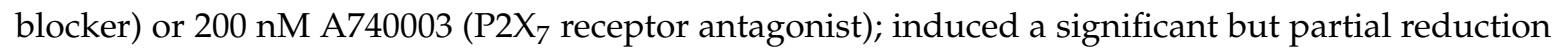
in the Etd uptake elicited by gp120 (Figure 2). In the same manner, neutralization of $\mathrm{P}_{2} \mathrm{Y}_{1}$ receptor activity with $10 \mu \mathrm{M}$ MRS2179 blunted the gp120-induced Etd uptake (Figure 2). Our data indicate that the activation of $C \times 43$ hemichannels and Panx1 channels induced by gp120 relies on the secretion of $\mathrm{IL}-1 \beta / \mathrm{TNF}-\alpha$ and the activation of $\mathrm{p} 38 \mathrm{MAPK} / \mathrm{iNOS} /\left[\mathrm{Ca}^{2+}\right]_{\mathrm{i}} / \mathrm{P}_{2} \mathrm{X}_{7} / \mathrm{P}_{2} \mathrm{Y}_{1}$-dependent cascades.

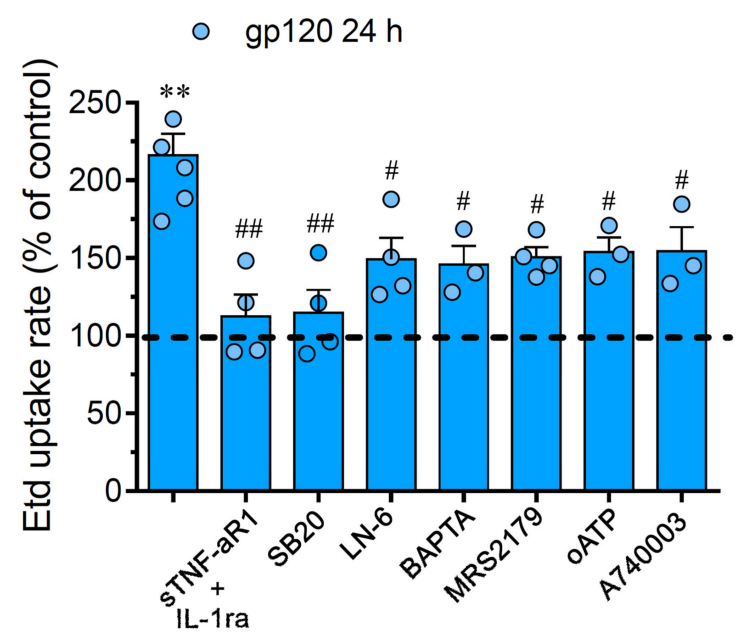

Figure 2. The gp120-induced Cx43 hemichannel and Panx1 channel function depends on IL-1 $\beta / T N F-\alpha$ signaling and activation of $\mathrm{p} 38 \mathrm{MAPK} / \mathrm{iNOS} / \mathrm{P} 2 \mathrm{X}_{7} / \mathrm{P}_{2} \mathrm{Y}_{1} /\left[\mathrm{Ca}^{2+}\right]_{\mathrm{i}}$-dependent pathways. Etd uptake rate normalized to control (dashed line) by astrocytes stimulated for $24 \mathrm{~h}$ with $10 \mathrm{ng} / \mathrm{mL}$ gp120 alone or plus the following agents: $100 \mathrm{ng} / \mathrm{mL}$ of IL-1ra+100 ng/mL of sTNF- $\alpha \mathrm{R} 1,1 \mu \mathrm{M}$ SB203580, $1 \mu \mathrm{M} \mathrm{L-N6}$, $10 \mu \mathrm{M}$ BAPTA, $1 \mu \mathrm{M}$ MRS2179; $200 \mu \mathrm{M}$ oxidized ATP (oATP) or $200 \mathrm{nM}$ A740003. ${ }^{* *} p<0.01$, gp120 vs. control; \# $p<0.05$, \#\# $p<0.01$; pharmacological agents vs. gp120. Data were obtained from at least three independent experiments (see scatter dot plot) with three or more repeats each one ( $\geq 30$ cells analyzed for each repeat).

\section{3. gp120 did not Affect Astrocyte-to-Astrocyte Coupling or the Distribution of Cx43 in Astrocytes}

Gap junctional-mediated coupling between astrocytes contributes to spatial buffering of $\mathrm{K}^{+}$, as well as the spread of energy substrates (e.g., lactate and glucose) and intercellular $\mathrm{Ca}^{2+}$ waves, these processes being critical to guarantee adequate neuronal function [47]. Relevantly, cell-cell uncoupling along with the increased opening of hemichannels and pannexons in astrocytes are concurrent phenomena that result in neuronal dysfunction and damage $[41,43,44]$. Keeping this into account, we evaluated whether gp120 alters the function of gap junction channels in astrocytes. 
Etd coupling experiments revealed that under control conditions, almost $100 \%$ of astrocytes were coupled (Figure 3A,B,E) and most of them did it with 14 neighboring astrocytes (Figure 3A,B,F). Surprisingly, $24 \mathrm{~h}$ of treatment with gp120 failed in alter astroglial coupling (Figure 3C-F) and the distribution of $\mathrm{Cx} 43$ in confluent astrocytes, the latter measured by immunofluorescence analysis (Figure 3G-J). Certainly, in both control and gp120-treated astrocytes, Cx43 was detected mostly and intensely as fine to large immunopositive spots scattered at cell-cell interfaces (Figure 3G-J). Altogether these findings indicate that gp120 specifically augments the function of Cx43 hemichannels but not the functional state of gap junction channels in astrocytes.
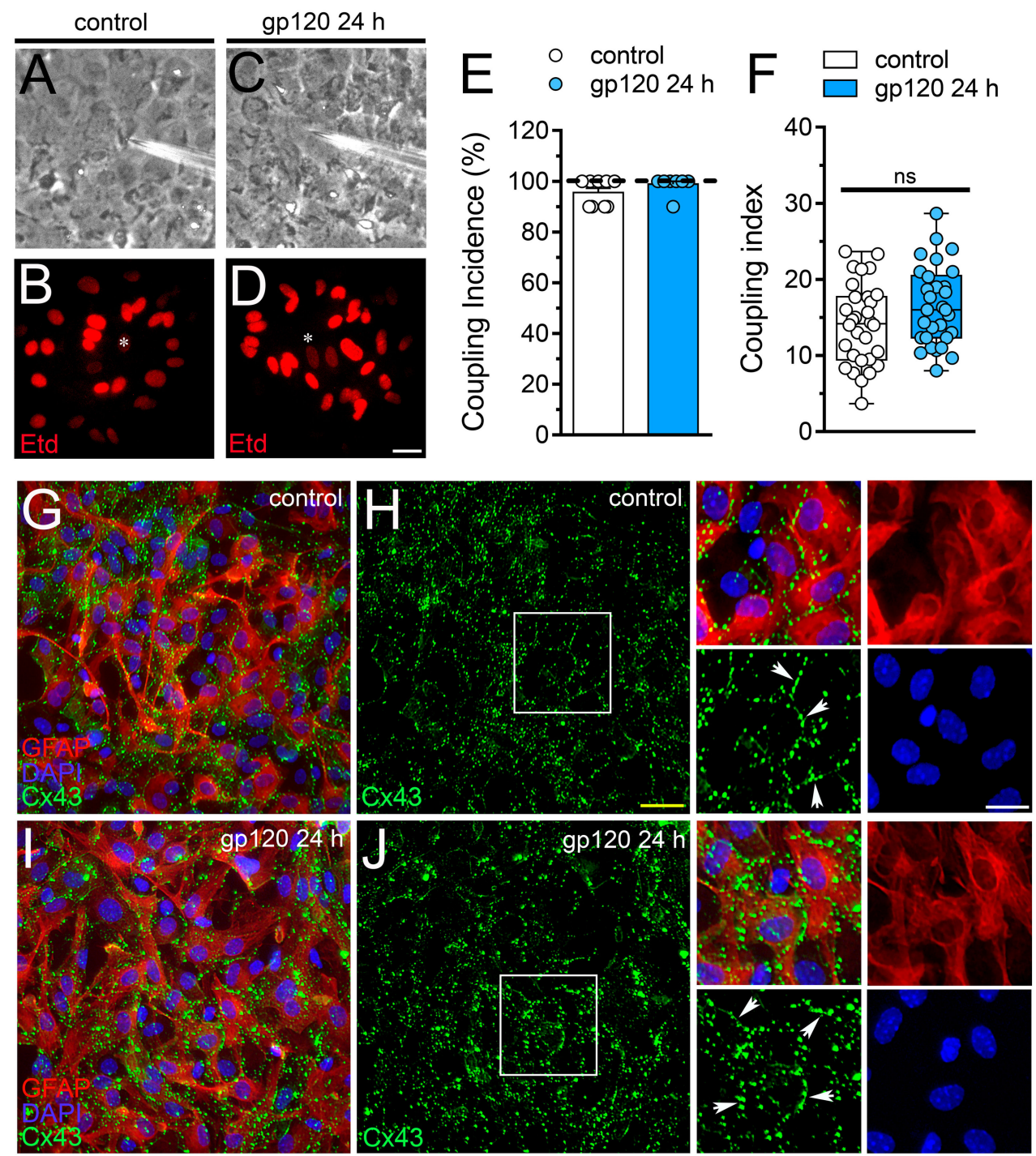

Figure 3. gp120 does not affect astroglial coupling or the distribution of Cx43 in astrocytes. (A-D) Fluorescence and phase-contrast micrographs of Etd transfer by astrocytes under control conditions (A,B) or stimulated for $24 \mathrm{~h}$ with $10 \mathrm{ng} / \mathrm{mL}$ gp120 (C,D). Yellow calibration bar $=60 \mu \mathrm{m}$. (E) Etd coupling incidence (percentage of injections that resulted in Etd transfer) of astrocytes under control conditions (white bar) or stimulated for $24 \mathrm{~h}$ with $10 \mathrm{ng} / \mathrm{mL}$ gp120 (blue bar). (F) Coupling index (number of cells coupled in positive injections) of astrocytes under control conditions (white bar) or stimulated for $24 \mathrm{~h}$ with $10 \mathrm{ng} / \mathrm{mL}$ gp120 (blue bar). White arrows indicate gap junction plaques at cell-cell interfaces. No significant differences were found. (G-J) Fluorescence images depicting Cx43 (green), GFAP (red) and DAPI (blue) staining by astrocytes under control conditions (G,H) or stimulated for $24 \mathrm{~h}$ with $10 \mathrm{ng} / \mathrm{mL}$ gp120 (I,J). Insets: $1.5 \times$ magnification of the white squares indicated area of panels $\mathrm{H}$ and J. Calibration bars: yellow $=120 \mu \mathrm{m}$ and white $=15 \mu \mathrm{m}$. 
2.4. The gp120-Induced Release of ATP Depends on the Opening of Panx1 Channels but not Cx43 Hemichannels in Astrocytes

Neuropathological scenarios often are accompanied by the release of ATP, which acts as a pleiotropic danger signal, triggering reactive astrogliosis and engagement of microglia and other peripheral immune cells that augment the susceptibility of neurons to damage [48]. Since Cx43 hemichannels and Panx1 channels allow the efflux of ATP in astrocytes $[35,49]$ and given that P2X $X_{7}$ and $\mathrm{P} \mathrm{Y}_{1}$ receptors take part in hemichannel/pannexon function elicited by gp120 (Figure 2), we further studied the release of this molecule. Incubation with gp120 for $24 \mathrm{~h}$ greatly raised the release of ATP by 3.7-folds in relation to untreated astrocytes (Figure 4). Both Tat-L2 or gap19 were ineffective in preventing this response, whereas ${ }^{10}$ panx 1 or probenecid fully counteracted the release of ATP elicited by gp120 (Figure 4). Collectively, this evidence implies that gp120 triggers the efflux of ATP in astrocytes by a mechanism that needs the opening of Panx1 channels but not $\mathrm{Cx} 43$ hemichannels.

\section{○ gp120 $24 \mathrm{~h}$}

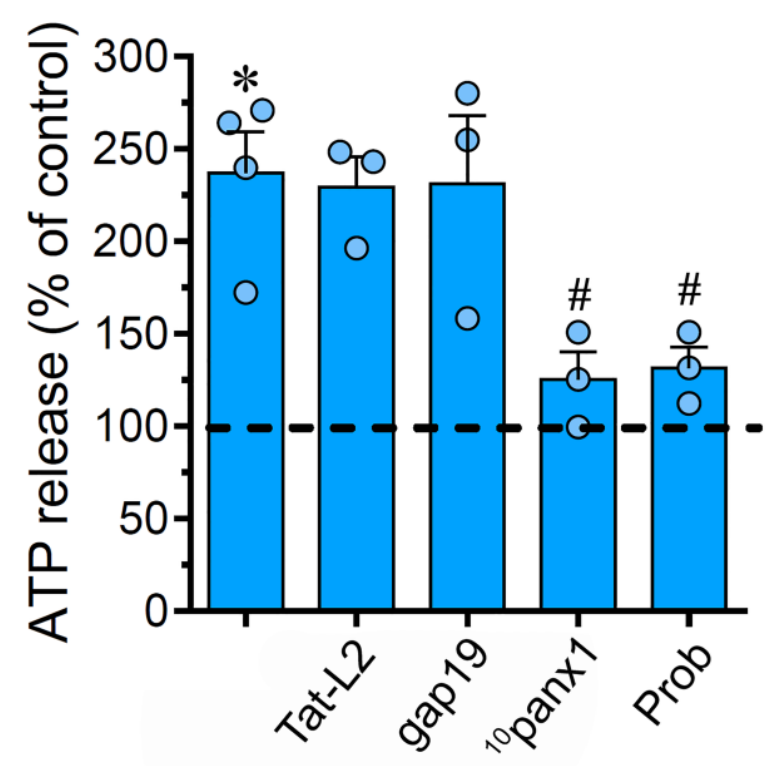

Figure 4. gp120 increases the release of ATP via the activation of Panx1 channels. ATP release normalized to the control (dashed line) by astrocytes stimulated for $24 \mathrm{~h}$ with $10 \mathrm{ng} / \mathrm{mL}$ gp120 alone or plus the following agents: $100 \mu \mathrm{M}$ Tat-L2, $100 \mu \mathrm{M}$ gap19, $100 \mu \mathrm{M}{ }^{10}$ panx1 and $500 \mu \mathrm{M}$ Probenecid (Prob). ${ }^{*} p<0.01$, gp120 vs. control; $\# p<0.01$, pharmacological agents vs. gp120. Data were obtained from at least three independent experiments (see scatter dot plot) with three or more repeats each one.

\subsection{The gp120-Induced Production of NO is Partially Mediated by the Activation of Cx43 Hemichannels and Panx1 Channels in Astrocytes}

The production of IL-1 $\beta$ and TNF- $\alpha$ has been proposed as a key element not only in the dysfunction of astrocytes [50], but also in the uncontrolled function of astroglial Cx43 hemichannels in pathological circumstances [41,51]. Considering this, along with the fact that sTNF-aR1 and IL-1ra dramatically counteracted the gp120-induced Etd uptake by astrocytes (Figure 2), we tested whether this viral protein could perturb the release of IL- $1 \beta$ and TNF- $\alpha$ in our system. Astrocytes stimulated with gp120 for $24 \mathrm{~h}$ displayed a 4.5 -fold and 6-fold rise in the secretion of IL- $1 \beta$ and TNF- $\alpha$ compared to untreated conditions, respectively (Figure 5A,B). Contrary to prior evidence indicating that the activation of hemichannels and pannexons contributes to the production of cytokines [39,52-54], we observed that Tat-L2, gap19 or ${ }^{10}$ panx1 did not reduce the gp120-induced release of IL-1 $\beta$ and TNF- $\alpha$. Increased iNOS activation and subsequent production of NO are downstream processes of IL- $1 \beta / \mathrm{TNF}-\alpha$ signaling and participate in reactive astrogliosis [55]. With this in mind and because LN-6, a specific iNOS blocker, significantly inhibited the gp120-induced Etd uptake in astrocytes (Figure 2), we evaluated whether 
Cx43 hemichannels or Panx1 channels disturbs NO production. Recordings of DAF-FM fluorescence signal showed that treatment with gp120 triggered a 3.3-fold increase in basal NO production in relation to control conditions (Figure 5C-E). Noteworthy, gap 19 or ${ }^{10}$ panx 1 strongly abolished this response (Figure 5C,F,G), unveiling that both Cx43 hemichannels and Panx1 channels were fundamental.
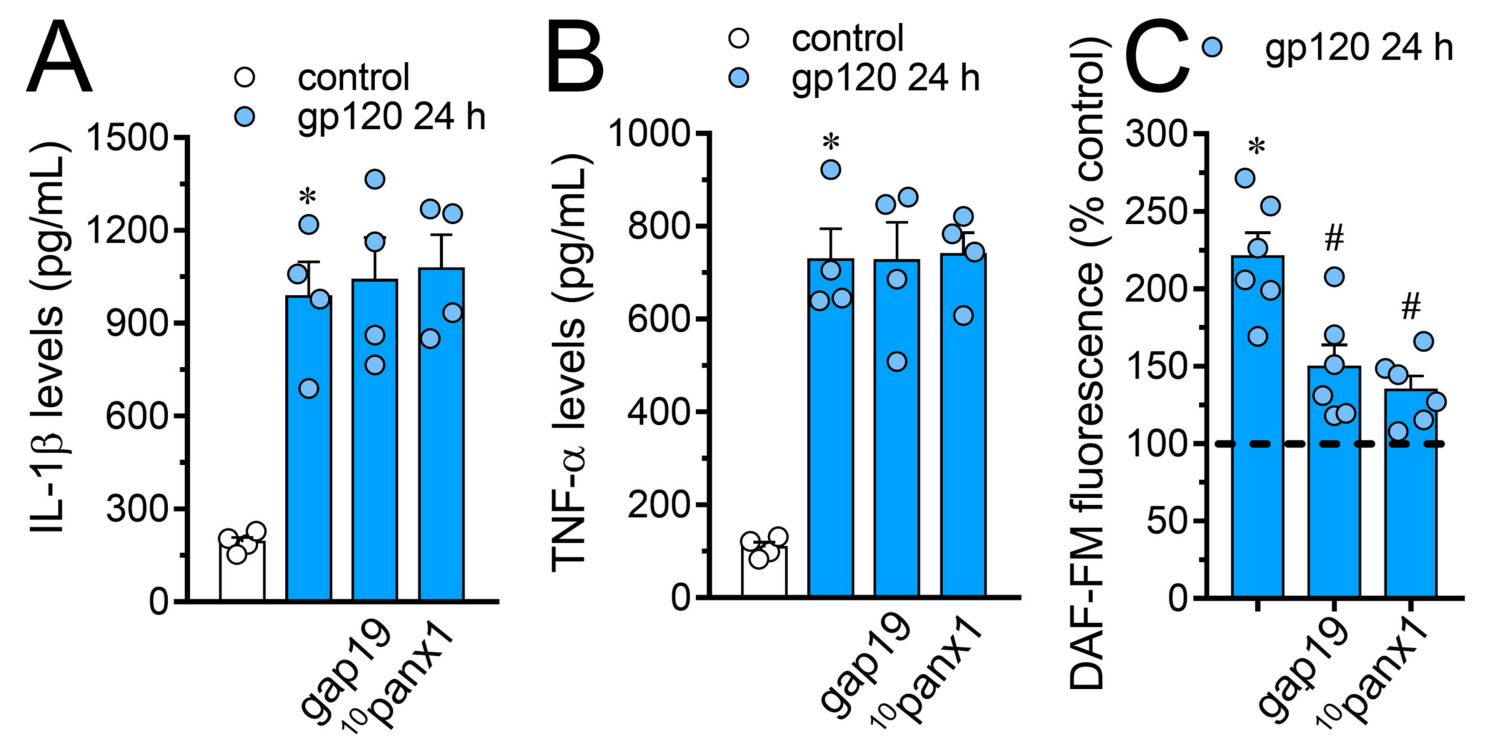

control

gp120 $24 \mathrm{~h}$
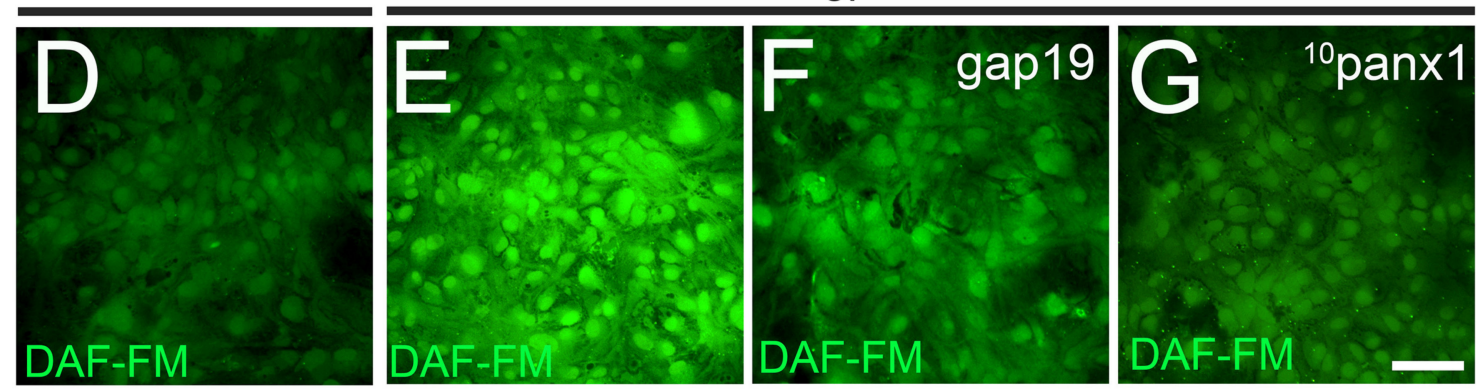

Figure 5. gp120 increases the release of IL-1 $\beta / T N F-\alpha$ and the production of NO in astrocytes: involvement of Cx43 hemichannels and Panx1 channels. (A,B) Amounts of IL-1 $\beta$ (A) and TNF- $\alpha$ (B) found in the extracellular media of astrocytes cultured under control conditions (white bars) or stimulated for $24 \mathrm{~h}$ with $10 \mathrm{ng} / \mathrm{mL}$ gp120 alone (blue bars) or plus the following agents: $100 \mu \mathrm{M}$ gap 19 or $100 \mu \mathrm{M}{ }^{10}$ panx1. ${ }^{*} p<0.001$, gp120 vs. control. Data were obtained from at least three independent experiments (see scatter dot plot) with three or more repeats each one. (C) DAF-FM fluorescence normalized to control (dashed line) by astrocytes stimulated for $24 \mathrm{~h}$ with $10 \mathrm{ng} / \mathrm{mL}$ gp 120 alone or plus the following agents: $100 \mu \mathrm{M}$ gap19 or $100 \mu \mathrm{M}{ }^{10}$ panx1. ${ }^{*} p<0.01$, gp120 treatment vs. control, $\# p<0.05$, pharmacological agents vs. gp120. Data were obtained from at least three independent experiments (see scatter dot plot) with three or more repeats each one ( $\geq 35$ cells analyzed for each repeat). (D-G) Fluorescence micrographs of basal NO production (DAF-FM, green) by astrocytes under control conditions (D) or stimulated for $24 \mathrm{~h}$ with $10 \mathrm{ng} / \mathrm{mL}$ gp120 alone (E) or plus $100 \mu \mathrm{M}$ gap19 (F) or $100 \mu \mathrm{M}{ }^{10}$ panx1 (G). Calibration bars: white $=80 \mu \mathrm{m}$. 
control
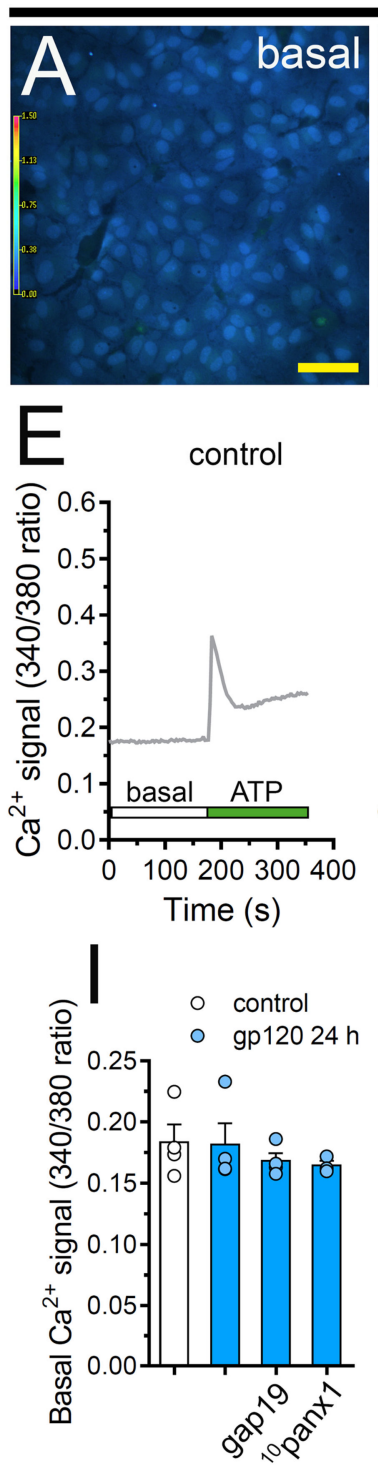

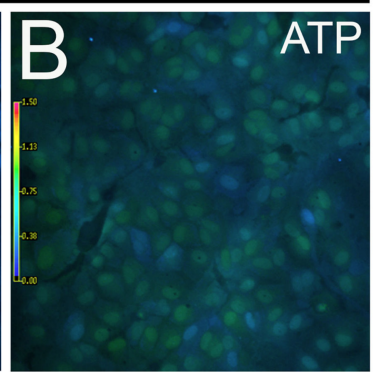

E
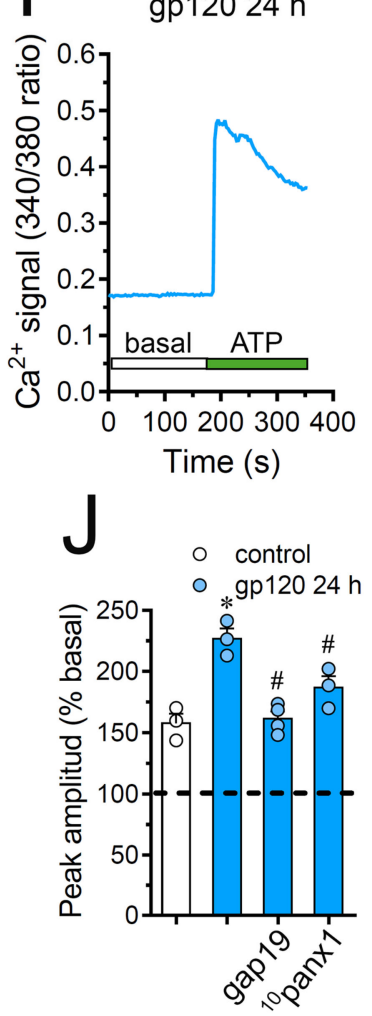

gp120 $24 \mathrm{~h}$
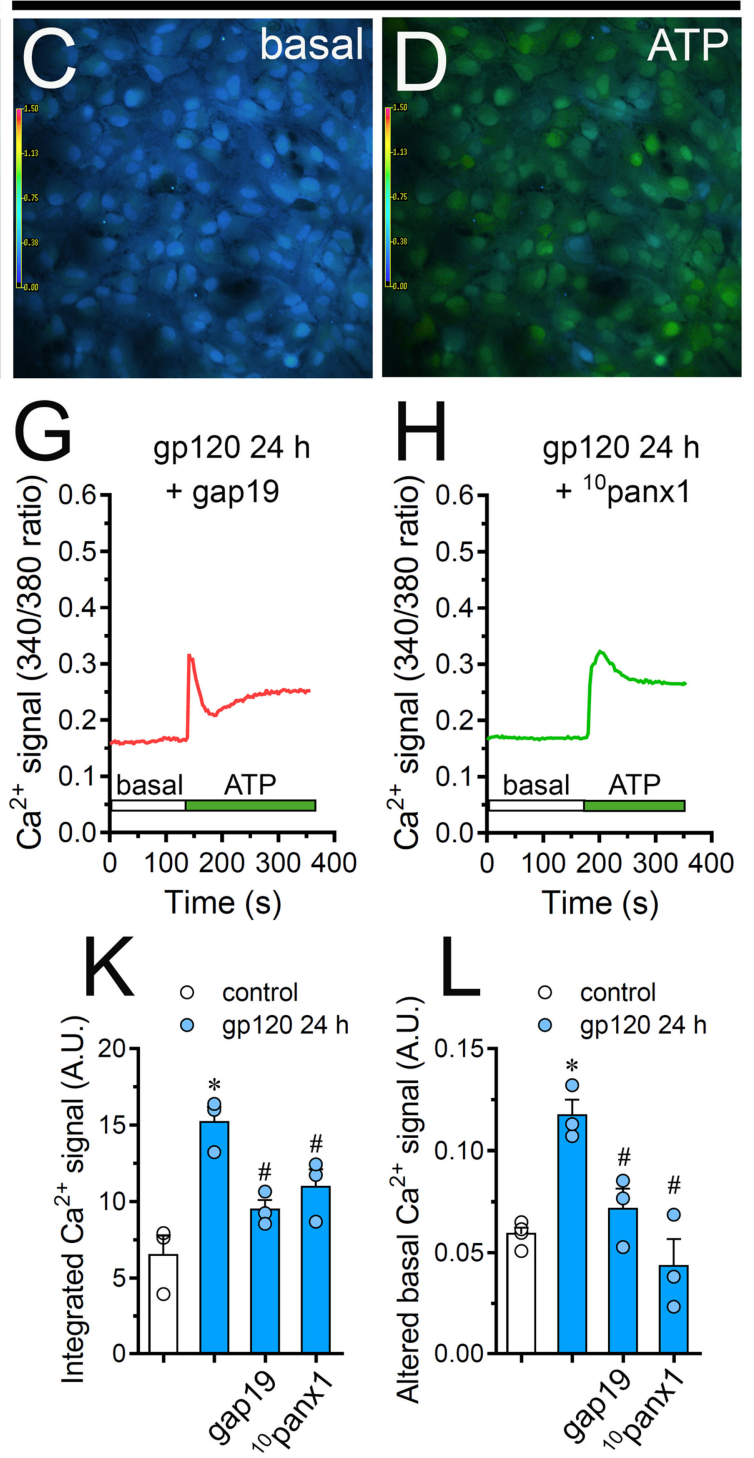

Figure 6. gp120 enhances ATP-dependent $\mathrm{Ca}^{2+}$ dynamics in astrocytes by a mechanism implicating the opening of Cx43 hemichannels and Panx1 channels. (A-D) Photomicrographs of basal (A,C) or $500 \mu \mathrm{M}$ ATP-induced (B,D) $\mathrm{Ca}^{2+}$ signal denoted as Fura-2 ratio (340/380 nm excitation) of astrocytes under control conditions (A,B) or stimulated for $24 \mathrm{~h}$ with $10 \mathrm{ng} / \mathrm{mL}$ gp120 (C, D). Calibration bar: $60 \mu \mathrm{m}$. (E-H) Relative changes in $\mathrm{Ca}^{2+}$ signal over time induced by $500 \mu \mathrm{M}$ ATP (green horizontal line) in astrocytes under control conditions (E) or stimulated for $24 \mathrm{~h}$ with $10 \mathrm{ng} / \mathrm{mL}$ gp120 (F) alone or plus the following agents: $100 \mu \mathrm{M}$ gap19 (G) and $100 \mu \mathrm{M}{ }^{10}$ panx1 (H). (I-L) Basal Fura-2 ratio (I), ATP-induced peak amplitude normalized to basal Fura-2 ratio (J), integrated ATP-induced Fura-2 ratio response (K) and altered basal Fura-2 ratio (L) by astrocytes under control conditions (white bars) or stimulated for $24 \mathrm{~h}$ with $10 \mathrm{ng} / \mathrm{mL}$ gp120 (blue bars) alone or plus the following agents: $100 \mu \mathrm{M}$ gap19 or $100 \mu \mathrm{M}^{10}$ panx1. ${ }^{*} p<0.05$, gp120 vs. control, $\# p<0.05$, pharmacological agents vs. gp120. Data were obtained from at least three independent experiments (see scatter dot plot) with three or more repeats each one ( $\geq 35$ cells analyzed for each repeat). 
2.6. Cx43 Hemichannels and Panx1 Channels Participate in the gp120-Induced Increase in ATP-Mediated $\left[\mathrm{Ca}^{2+}\right]_{i}$ Dynamics by Astrocytes

Changes in astroglial $\left[\mathrm{Ca}^{2+}\right]_{i}$ dynamics and the opening of $\mathrm{C} x 43$ hemichannels are mutual processes that occur in neuroinflammatory scenarios $[42,56,57]$. Given this and because intracellular BAPTA significantly blunted gp120-dependent Etd uptake (Figure 2), we examined if gp120 could modulate the basal $\mathrm{Ca}^{2+}$ signal in astrocytes. Recordings of Fura-2 ratio (340/380) showed that gp120 did not produce relevant disturbances in basal $\mathrm{Ca}^{2+}$ levels in relation to control conditions (Figure 6A,C,E,F,I). Nonetheless, the above does not rule out whether gp120 could alter $\mathrm{Ca}^{2+}$ dynamics evoked by autocrine/paracrine signals. Since extracellular levels of ATP were found increased in astrocytes treated with gp120 (Figure 4), we studied the impact of this viral protein on ATP-mediated $\mathrm{Ca}^{2+}$ dynamics. As previously shown [44], $500 \mu \mathrm{M}$ ATP induced a quick $\mathrm{Ca}^{2+}$ signal response with a slight amplitude in control astrocytes (Figure 6B,E,J). However, gp120 caused a prominent ATP-mediated $\mathrm{Ca}^{2+}$ signal with an amplitude 2-fold bigger than control values (Figure 6D,FJ). This response took place in parallel with a 2.5-fold and 2-fold rise in the integrated area under curve of ATP-dependent $\mathrm{Ca}^{2+}$ response (Figure $6 \mathrm{~K}$ ) and the residual difference between the final and initial basal $\mathrm{Ca}^{2+}$ signal (Figure $6 \mathrm{~L}$ ), respectively.

It has been proposed that both hemichannels and pannexons are conduits for $\mathrm{Ca}^{2+}[58,59]$ and regulate cytoplasmic $\mathrm{Ca}^{2+}$ dynamics through the efflux of signals (e.g., ATP) [46]. Consistent with this idea, we noted that the blockade of Cx43 hemichannels or Panx1 channels with gap19 or ${ }^{10}$ panx1 strongly diminished the increase in ATP-mediated $\mathrm{Ca}^{2+}$ signal amplitude triggered by gp120 (Figure 6G,H,J). In a similar way, the blockade of $\mathrm{Cx} 43$ hemichannels and Panx1 channels prominently abolished the augment in the area under the curve and remaining basal ATP-dependent $\mathrm{Ca}^{2+}$ responses induced by gp120 (Figure $6 \mathrm{~K}, \mathrm{~L}$ ). On the whole, these data point out that the function of Cx43 hemichannels and Panx1 channels participate in the gp120-induced rise of ATP-mediated $\mathrm{Ca}^{2+}$ dynamics in astrocytes.

\section{7. gp120 Elevates the Function of Astroglial Cx43 Hemichannels and Panx1 Channels in the Hippocampus}

To scrutinize the impact of gp120 on astrocytes embraced in a more physiological context, we explored if this viral protein could modify the function of hemichannels and pannexons in hippocampal astrocytes from acute brain slices. Etd uptake by GFAP-positive astrocytes was examined in three areas of the hippocampus: the stratum oriens, stratum pyramidale and stratum radiatum. In control brain slices, astrocytes displayed a slight Etd uptake in all CA1 studied areas (Figures 7A, 8A and 9A). Nevertheless, following 30 min of gp120 stimulation, the hippocampus exhibited astrocytes with enhanced Etd uptake at the stratum oriens (11.3-fold, Figure 7B-C), stratum pyramidale (8-fold, Figure $8 \mathrm{~B}-\mathrm{C}$ ) and stratum radiatum (12.5-fold, Figure $9 \mathrm{~B}-\mathrm{C})$. Analysis of the temporal responses uncovered that Etd uptake quickly rose following $30 \mathrm{~min}$ of gp120 treatment but gradually declined over the hours (Figures 7A, 8A and 9A). Further, acute brain slices were preincubated for $15 \mathrm{~min}$ before and during Etd uptake experiments with inhibitors for Cx43 hemichannels or Panx 1 channels in order to inspect their contribution in these responses. Equivalent to what we observed in astrocyte cultures (Figure 1F), $100 \mu \mathrm{M}^{10}$ panx1 significantly abolished the gp120-induced Etd uptake observed in astrocytes from the stratum oriens (45\%, Figure 7D), stratum pyramidale (46\%, Figure 8D) and stratum radiatum (36\%, Figure 9D). Nevertheless, gap19 $(100 \mu \mathrm{M})$ was successful in diminishing Etd uptake only in the stratum oriens (33\%, Figure 7D) but not in the stratum pyramidale (Figure 8D) or stratum radiatum (Figure 9D). Taking together these findings show that gp120 augments the function of astroglial Panx1 channels in at distinct hippocampal regions, whereas its stimulatory effect on astroglial Cx43 hemichannels is restricted to the stratum oriens. 

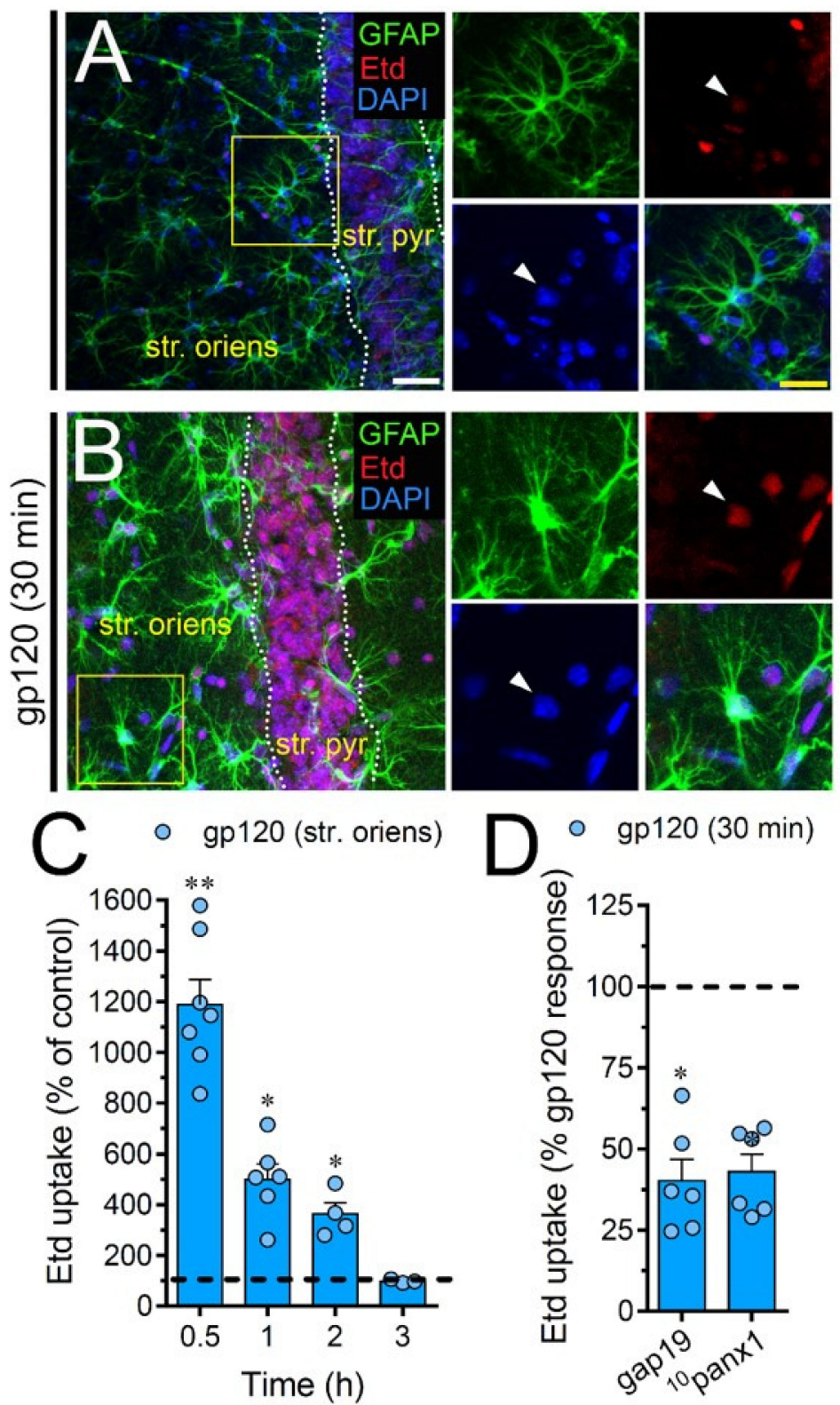

Figure 7. gp120 enhances Cx43 hemichannel and Panx1 channel function in hippocampal astrocytes from the stratum oriens. (A,B) GFAP (green), Etd (red) and DAPI (blue) staining in the stratum oriens of brain slices under control conditions (A) or stimulated for $30 \mathrm{~min}$ with $10 \mathrm{ng} / \mathrm{mL}$ gp120 (B). Insets of astrocytes were taken from the area depicted within the yellow squares in panels A and B, whereas arrowheads indicate their cell bodies. (C) Etd uptake normalized to control (dashed line) by astrocytes in the stratum oriens from brain slices after distinct periods of exposure to $10 \mathrm{ng} / \mathrm{mL}$ gp $120 .{ }^{* *} p<0.001$, * $p=0.05$, gp120 vs. control ( $\geq 35$ cells analyzed for at least three independent experiments). (D) Etd uptake normalized to the maximum response evoked by gp120 (dashed line) by astrocytes in the stratum oriens from brain slices after $30 \mathrm{~min}$ of exposure to $10 \mathrm{ng} / \mathrm{mL}$ plus gap19 $(100 \mu \mathrm{M})$ or ${ }^{10}$ panx1 $(100 \mu \mathrm{M}) .{ }^{*} p<0.01,30 \mathrm{~min}$ gp120 vs. blockers. ( $\geq 33$ cells analyzed for at least three independent experiments). Calibration bars: white bar $=120 \mu \mathrm{m}$; yellow bar: $85 \mu \mathrm{m}$. 

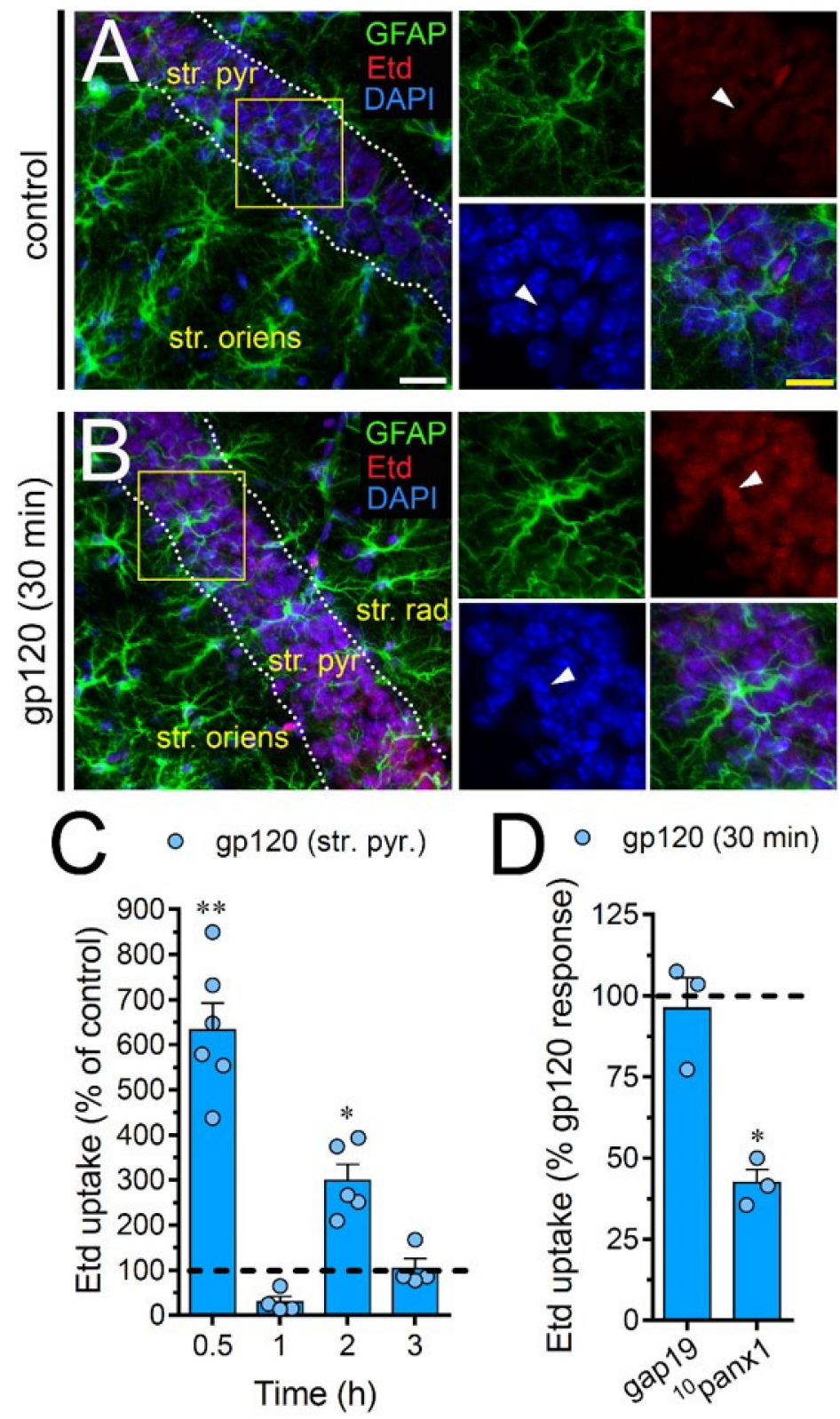

Figure 8. gp120 enhances Panx1 channel function in hippocampal astrocytes from the stratum pyramidale. (A-B) GFAP (green), Etd (red) and DAPI (blue) staining in the stratum pyramidale of brain slices under control conditions (A) or stimulated for $30 \mathrm{~min}$ with $10 \mathrm{ng} / \mathrm{mL} \mathrm{gp120}$ (B). Insets of astrocytes were taken from the area depicted within the yellow squares in panels A and B, whereas arrowheads indicate their cell bodies. (C) Etd uptake normalized to control (dashed line) by astrocytes in the stratum pyramidale from brain slices after distinct periods of exposure to $10 \mathrm{ng} / \mathrm{mL} \mathrm{gp} 120$. ${ }^{* *} p<0.001,{ }^{*} p=0.05$, gp120 vs. control. ( $\geq 35$ cells analyzed for at least three independent experiments). (D) Etd uptake normalized to maximum response evoked by gp120 (dashed line) by astrocytes in the stratum pyramidale from brain slices after $30 \mathrm{~min}$ of exposure to $10 \mathrm{ng} / \mathrm{mL}$ gp120 plus gap19 $(100 \mu \mathrm{M})$ or ${ }^{10}$ panx1 $(100 \mu \mathrm{M}) .{ }^{*} p<0.01,30 \mathrm{~min}$ gp120 vs. blockers $(\geq 33$ cells analyzed for at least three independent experiments). Calibration bars: white bar $=120 \mu \mathrm{m}$; yellow bar: $85 \mu \mathrm{m}$. 

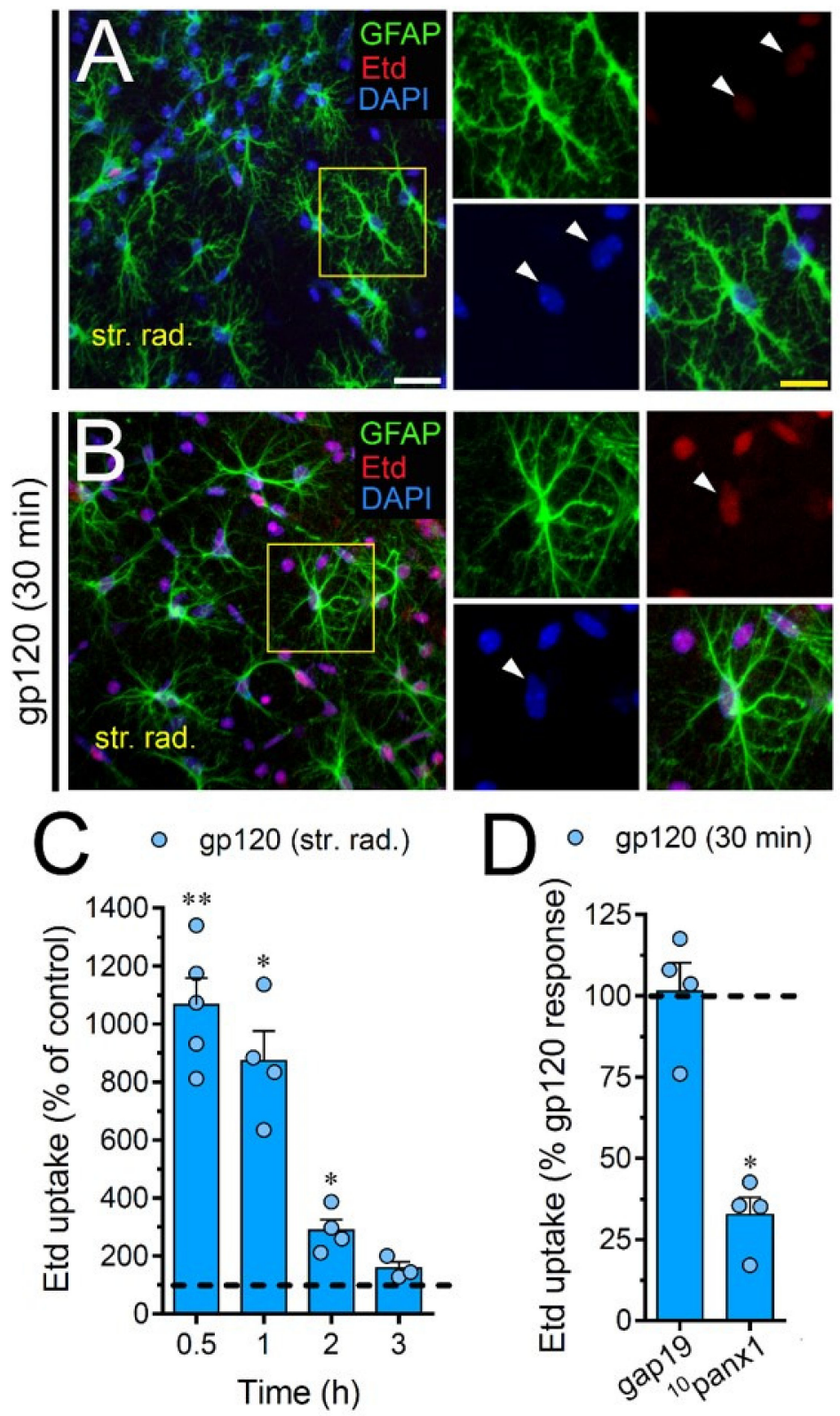

Figure 9. gp120 enhances Panx1 channel function in hippocampal astrocytes from the stratum radiatum. (A,B) GFAP (green), Etd (red) and DAPI (blue) staining in the stratum radiatum of brain slices under control conditions (A) or stimulated for $30 \mathrm{~min}$ with $10 \mathrm{ng} / \mathrm{mL}$ gp120 (B). Insets of astrocytes were taken from the area depicted within the yellow squares in panels $A$ and $B$, whereas arrowheads indicate their cell bodies. (C) Etd uptake normalized to control (dashed line) by astrocytes in the stratum radiatum from brain slices after distinct periods of exposure to $10 \mathrm{ng} / \mathrm{mL} \mathrm{gp} 120$. ${ }^{* *} p<0.001,{ }^{*} p=0.05$, gp120 vs. control ( $\geq 35$ cells analyzed for at least three independent experiments). (D) Etd uptake normalized to the maximum response evoked by gp120 (dashed line) by astrocytes in the stratum radiatum from brain slices after $30 \mathrm{~min}$ of exposure to $10 \mathrm{ng} / \mathrm{mL}$ gp120 plus gap19 $(100 \mu \mathrm{M})$ or ${ }^{10}$ panx1 $(100 \mu \mathrm{M})$. ${ }^{*} p<0.01,30 \mathrm{~min}$ gp120 vs. blockers ( $\geq 33$ cells analyzed for at least three independent experiments). Calibration bars: white bar $=120 \mu \mathrm{m}$; yellow bar: $85 \mu \mathrm{m}$.

\section{Discussion}

Here, we demonstrated that gp120 increased the function of Cx43 hemichannels and Panx1 channels in astrocytes. This stimulatory effect took place via the signaling of IL- $1 \beta / \mathrm{TNF}-\alpha$ and the activation of $\mathrm{p} 38 \mathrm{MAPK} / \mathrm{iNOS} /\left[\mathrm{Ca}^{2+}\right]_{\mathrm{i}}$-dependent cascades and $\mathrm{P} 2 \mathrm{Y}_{1} / \mathrm{P} 2 \mathrm{X}_{7}$ purinergic receptors. 
Remarkably, the function of Cx43 hemichannels and Panx1 channels evoked by gp120 was crucial for inducing severe alterations in ATP release, NO production and $\left[\mathrm{Ca}^{2+}\right]_{i}$ dynamics in astrocytes.

Time-lapse recordings of Etd uptake demonstrated that gp120 increased the function of Cx43 hemichannels and Panx1 channels in a time and concentration-dependent form in primary cortical astrocytes. Two well-recognized specific mimetic peptides that antagonize Cx43 hemichannel opening (Tat-L2 and gap19), drastically neutralized the gp120-induced Etd uptake. In addition, the inhibition of Panx 1 channels with ${ }^{10}$ panx 1 or probenecid resulted in similar antagonistic effects, revealing that both Cx43 hemichannels and Panx1 channels were significant protagonists in the gp120-induced Etd uptake. These data are consistent with prior in vitro and ex vivo studies describing the parallel opening of both channels in astrocytes subjected to neuroinflammatory conditions such as FGF-1 [60], alcohol [61], ultrafine carbon black [62], gp120 [44], familial Alzheimer's disease [63], spinal cord injury [64] and acute infection [65].

The functional state of gap junction channels and hemichannels is inversely modulated in inflamed astrocytes [41,66]. In discrepancy with this evidence, we observed that gp120 did not reduce astroglial coupling, as recorded by intercellular Etd transfer. As inferred from confocal immunofluorescence studies, gp120 had no effects on the localization of Cx43 in astrocytes, suggesting that the organization of gap junctions remain unaltered. One hypothesis to explain this apparent contradiction is that gap junctions could keep their functional state to spread and amplify gp120-mediated toxic substances. The latter it has been demonstrated to occur between HIV-1-infected and uninfected astrocytes [20]. The variety of potentially toxic molecules diffusing through gap junction is wide, ranging from free radicals to high concentrations of cytoplasmic $\mathrm{Ca}^{2+}$, as well as $\mathrm{IP}_{3}[67-70]$.

Mounting evidence has shown that gp120 triggers the persistent activation of astrocytes associated with a broad-spectrum generation of inflammatory signals, including IL- $1 \beta$ and TNF- $\alpha$ [71,72]. Certainly, the expression of both cytokines augments in postmortem brains of HIV-1 patients [73] and their signaling linked to the p38 MAPK pathway opens astroglial Cx43 hemichannels $[41,44,51,74]$. By making use of a combination of selective inhibitors, we observed that gp120-induced Etd uptake embraces the activation of IL-1 $\beta / \mathrm{TNF}-\alpha$ and p38 MAPK, being this consistent with the fact that gp120 stimulates p38 MAPK in astrocytes [75]. Downstream signaling of IL-1 $\beta / T N F-\alpha$ and p38 MAPK leads to the expression of iNOS [76] and, in consequence, increases the amounts of NO [77]. Despite that NO is essential for synaptic transmission and plasticity [78], its high production has been linked to astroglial-mediated neurotoxicity [79] and the opening of astroglial Cx43 hemichannels via NO-mediated S-nitrosylation of Cx43. Conformity with this, we found that gp120 dramatically augmented NO production in astrocytes, this effect being moderately abrogated by inhibition of Cx43 hemichannels or Panx1 channels. The latter harmonizes with previous studies describing that activation of $\mathrm{C} x 43$ hemichannels/Panx1 channels and NO production are reciprocal processes occurring on glial cells exposed to proinflammatory conditions $[44,80]$.

Prior data indicate that gp120 may induce the release of several "danger" signals from glial cells, including ATP [81], the latter molecule being recently proposed as a biomarker of HIV-1-mediated cognitive impairment [82]. With this in mind, two significant elements underscore the importance of ATP signaling on the gp120-induced astrocyte changes in our system. On the one hand, we found that suppression of both $\mathrm{P} 2 \mathrm{X}_{7}$ and $\mathrm{P} 2 \mathrm{Y}_{1}$ receptors greatly abrogated the Etd uptake evoked by gp120. At the other end, the activation of Panx1 channels was crucial for the release of ATP in gp120-stimulated astrocytes. Previous evidence has highlighted that ATP causes its release through hemichannels or pannexons, leading to the subsequent stimulation of purinergic receptors $[44,74,83]$. We conjecture that ATP release may serve as a downstream mechanism that results in the opening of $\mathrm{Cx} 43$ hemichannel and/or Panx1 channels, where $\mathrm{P}_{2} \mathrm{Y}_{1} / \mathrm{P} 2 \mathrm{X}_{7}$ receptor-dependent rise in $\left[\mathrm{Ca}^{2+}\right]_{\mathrm{i}}$ could be fundamental, as already reported $[44,74,83]$. Indeed, a mild rise in $\left[\mathrm{Ca}^{2+}\right]_{i}$ up to $500 \mathrm{nM}$ significantly reinforces the function of Cx43 hemichannels [42], while analogous responses seem to occur in Panx1 channels [45]. In this line, we observed that BAPTA, strongly reduced the gp120-induced Etd uptake in astrocytes. This is consistent with recent works showing that gp120 increases $\left[\mathrm{Ca}^{2+}\right]_{\mathrm{i}}$ in astrocytes [84] and that 
purinergic receptors are critical for HIV infection and gp120-mediated signaling [85,86]. Alongside this, given that $\mathrm{C} \times 43$ hemichannels are permeable to $\mathrm{Ca}^{2+}[56]$ and one could infer the same for Panx1 channels $[58,87]$, they potentially may contribute to sustaining $\left[\mathrm{Ca}^{2+}\right]_{\mathrm{i}}$-dependent pathways linked to ATP release (see below).

Both the P2Y receptor-dependent release of internal $\mathrm{Ca}^{2+}$ and its extracellular influx via P2X receptors are emblematic astrocyte $\left[\mathrm{Ca}^{2+}\right]_{i}$ responses evoked by ATP [88]. In this study, we observed that although gp120 had no consequences on basal levels of $\left[\mathrm{Ca}^{2+}\right]_{i}$, it caused a drastic augment in ATP-induced $\mathrm{Ca}^{2+}$ responses, particularly, concerning the signal amplitude, integrated area under the curve and sustained signal. Worthy of note, the blockade of Cx43 hemichannels or Panx1 channels strongly antagonized the increased ATP-mediated $\left[\mathrm{Ca}^{2+}\right]_{\mathrm{i}}$ responses triggered by gp120. With this in mind, we speculated that the release of ATP and/or its derivates (e.g., ADP) from astrocytes might spread the gp120-mediated signaling to neighboring cells, resulting in $\mathrm{Ca}^{2+}$ responses that may impair the function and eventually the survival of glial cells and neurons. In such circumstances, the opening of Cx43 hemichannels and Panx1 channels could be crucial, whereas the signaling of purinergic receptors likely will be counteracted by 1 ) diffusion of ATP towards distant areas; 2) desensitization of

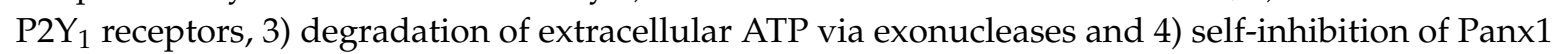
channels by the direct action of ATP [89,90].

Although in vitro culture preparations are useful to dissect cellular mechanisms, they not always recapitulate the processes that take place in vivo. As a result of the use of acute brain slices, we corroborated in a much comprehensive model the stimulatory action of gp120 on Cx43 hemichannel/Panx1 channel function observed in astrocyte cultures. It is relevant to mention that gp120 exposure quickly augmented in a transient form the opening of Panx1 channels overall in the CA1 region, but only reproduce this effect on Cx43 hemichannel function in the stratum oriens. One plausible explanation is the existence of local stimuli (e.g., elevation in extracellular $\mathrm{K}^{+}$) affecting specifically Panx1 channels rather than Cx43 hemichannels in the CA1 region of the hippocampus. Alternatively, the differential influence of gp120 on channel opening may rely on the unique topological organization of hippocampal area CA1 astrocytes and pyramidal neurons [91]. For instance, astrocytes near to the stratum pyramidale are arranged in circuits that stay parallel to this layer, while astrocytes in the stratum radiatum constitute circular circuits [92].

Similarly, although the number of astrocytes remains unchanged between young and middle-aged mice, their quantity declines with the age in the stratum oriens, whereas the opposite occurs in the stratum lacunosum-moleculare [93]. In the same line, the electrophysiological features, cell-cell coupling, antigen profiles and $\left[\mathrm{Ca}^{2+}\right]_{\mathrm{i}}$ responses of astrocytes at the hippocampus are diverse depending on their location in this brain region [91,93-95]. The heterogeneity of neuronal types (e.g., pyramidal, baskets, etc.) and their projections (e.g., inhibitory and excitatory) is another factor that turns even more complex in these analyses. Likely, this diversity may account for the gp120-induced mediated heterogeneity in channel responses in the regions analyzed. Further research is required to unveil the mechanisms of these differential effects.

Overall, our findings support the idea that gp120-induced hemichannel/pannexon activation could occur rapidly upon HIV-1 brain invasion and being consequences of this process: i) the increase in ATP release, ii) the augment of NO production and iii) the rise in ATP-mediated $\left[\mathrm{Ca}^{2+}\right]_{\mathrm{i}}$, dynamics. We propose a novel mechanism by which gp120 could disturb the astrocyte function implicating the successive activation of inflammatory cascades that in consequence enhance the activation of astroglial hemichannels and pannexons. The molecular mechanisms behind this phenomenon could serve as pharmacological targets for exploring new therapies aiming to tackle the pathogenesis and progression of HAND. 


\section{Materials and Methods}

\subsection{Reagents and Antibodies}

Dulbecco's Modified Eagle Medium (DMEM), water, L-N6, SB203580, MRS2179, oxidized ATP (oATP), HEPES, anti-GFAP monoclonal antibody, A74003, Cx43 rabbit polyclonal antibody (SAB4501174), ethidium (Etd) bromide and probenecid (Prob) were purchased from Sigma-Aldrich (St. Louis, MO, USA). Anti-Cx43 monoclonal antibody (610061) was obtained from BD Biosciences (Franklin Lakes, NJ, USA). Penicillin, BAPTA-AM, FURA-2AM, diamidino-2-phenylindole (DAPI), goat anti-mouse Alexa Fluor 488, streptomycin, DAF-FM diacetate, goat anti-mouse Alexa Fluor 488/555 and goat anti-rabbit Alexa Fluor 488/555 were from Thermo Fisher Scientific (Waltham, MA, USA). Fetal bovine serum (FBS) was purchased from Hyclone (Logan, UT, USA). Normal goat serum (NGS) was purchased from Zymed (San Francisco, CA, USA). A soluble form of the TNF- $\alpha$ receptor (sTNF- $\alpha$ R1) and a recombinant receptor antagonist for IL-1 $\beta$ (IL-1ra) were from R\&D Systems (Minneapolis, MN, USA). The mimetic peptides gap19 (KQIEIKKFK, intracellular loop domain of Cx43), gap19 ${ }^{\mathrm{I130A}}$ (KQAEIKKFK, negative control), Tat-L2 (YGRKKRRQRRR-DGANVDMHLKQIEIKKFKYGIEEHGK, second intracellular loop domain of Cx43), Tat-L2 ${ }^{\mathrm{H} 126 \mathrm{~K} / \mathrm{I} 130 \mathrm{~N}}$ (YGRKKRRQRRR-DGANVDMKLKQN EIKKFKYGIEEHGK, negative control) and ${ }^{10}$ panx1 (WRQAAFVDSY, first extracellular loop domain of Panx1) were obtained from Genscript (New Jersey, NJ, USA). The HIV-1 BaL gp120 recombinant protein recombinant protein (Cat\#4961) was obtained from the NIH AIDS Reagent Program, Division of AIDS, NIAID and NIH.

\subsection{Animals}

C57BL/6 (PUC/The Jackson Laboratory) male mice of 2-month-old were housed in cages at temperature- $\left(24^{\circ} \mathrm{C}\right)$ and humidity-controlled ambient under a $12 \mathrm{~h}$ light/dark cycle (lights on 8:00 AM), with ad libitum access to food and water. Animal protocols were conducted following the guideline and approved protocol for care and use of experimental animals of the Bioethics Committee of the Pontificia Universidad Católica de Chile (PUC; $n^{\circ}:$ 150806013, 6 June 2016).

\subsection{Cell Cultures}

Primary cultures of cortical astrocytes were obtained from cortices of postnatal day 2 mice as previously reported [44]. After dissection of cortices, meninges were carefully peeled off and tissue was mechanically dissociated in $\mathrm{Ca}^{2+}$ and $\mathrm{Mg}^{2+}$ free Hank's balanced salt solution (CM-HBSS) with $0.25 \%$ trypsin and $1 \%$ DNase. Cells were seeded onto 60-mm plastic dishes (Corning, NY, USA) or onto glass coverslips (Fisher Scientific, Waltham, MA, USA) placed inside 16-mm 24-well plastic plates (Corning, NY, USA) in DMEM, supplemented with streptomycin (5 $\mathrm{gg} / \mathrm{mL})$, penicillin $(5 \mathrm{U} / \mathrm{mL})$ and $10 \%$ FBS. Cells were grown at $37^{\circ} \mathrm{C}$ in a $5 \% \mathrm{CO}_{2} / 95 \%$ air atmosphere at nearly $100 \%$ relative humidity. Of cytosine-arabinoside $1 \mu \mathrm{M}$ was added for 3 days after 8-10 days in vitro to eliminate proliferating microglia. Medium was changed twice a week and cultures were used after 3 weeks.

\subsection{Treatments}

Astrocytes were treated for 0, 1, 24, 48 or $72 \mathrm{~h}$ with 1, 5, 10 or $20 \mathrm{ng} / \mathrm{mL}$ of HIV-1 BaL gp120 (from now on referred as to "gp120"). To obtain conditioned media (CM) from astrocytes, cells $\left(2 \times 10^{6}\right.$ cells in $35 \mathrm{~mm}$ dishes) were treated with $10 \mathrm{ng} / \mathrm{mL}$ gp120 for $24 \mathrm{~h}$ and supernatants filtered $(0.22 \mu \mathrm{m})$, and stored at $-20^{\circ} \mathrm{C}$ before used for experiments. Different antagonists were preincubated $1 \mathrm{~h}$ prior and co-incubated with $10 \mathrm{ng} / \mathrm{mL}$ gp120 before experiments: mimetic peptides against Cx43 hemichannels (Tat-L2 and gap19, $100 \mu \mathrm{M})$ and Panx1 channels ( ${ }^{10}$ panx1, $\left.100 \mu \mathrm{M}\right)$, Prob (Panx1 channel blocker, $500 \mu \mathrm{M}$ ), sTNF- $\alpha \mathrm{R} 1$ (soluble form of the receptor that binds TNF- $\alpha$ ), IL-1ra (IL-1 $\beta$ receptor endogenous blocker), SB203580 (p38 MAP kinase inhibitor, $1 \mu \mathrm{M}$ ), L-N6 (iNOS inhibitor, $1 \mu \mathrm{M}$ ), BAPTA-AM (intracellular $\mathrm{Ca}^{2+}$ chelator, $10 \mu \mathrm{M}$ ), oATP (general P2X receptor blocker, $200 \mu \mathrm{M}$ ), MRS2179 (P2Y 1 receptor blocker, $1 \mu \mathrm{M}$ ) and A740003 (P2X 7 receptor blocker, $200 \mathrm{nM}$ ). 


\subsection{Dye Uptake and Time-lapse Fluorescence Imaging}

Astrocytes plated on glass coverslips were washed twice in Hank's balanced salt solution and bathed at room temperature with Locke's solution $(154 \mathrm{mM} \mathrm{NaCl}, 5.4 \mathrm{mM} \mathrm{KCl}, 2.3 \mathrm{mM} \mathrm{CaCl} 2,5 \mathrm{mM}$ HEPES, pH 7.4) containing $5 \mu \mathrm{M}$ Etd. Cells were then visualized with an Olympus BX 51W1I upright microscope with a $40 \times$ water immersion objective for time-lapse imaging. Images were captured using a Retiga 1300I fast-cooled monochromatic digital camera (12-bit; Qimaging, Burnaby, BC, Canada) controlled by imaging Metafluor software (Universal Imaging, Downingtown, PA) every $30 \mathrm{~s}$ (exposure time $=0.5 \mathrm{~s}$; excitation and emission wavelengths were $528 \mathrm{~nm} 598 \mathrm{~nm}$, respectively). The fluorescence intensity recorded from $\geq 30$ regions of interest (representing at least 30 cells per cultured coverslip) was defined with the following formula: corrected total cell Etd fluorescence $=$ integrated density $-(($ area of the selected cell $) \times($ mean fluorescence of background readings)). The Etd uptake rate represent the mean slope of the relationship over a given time interval $(\Delta \mathrm{F} / \Delta \mathrm{T})$. To examine variations in the slope, regression lines were fitted using Microsoft Excel, and mean slope values were analyzed employing GraphPad Prism software and expressed as AU/min. In each independent experiment three replicates were performed. In some experiments, cultured astrocytes were preincubated with gap19 $(100 \mu \mathrm{M})$, Tat-L2 $(100 \mu \mathrm{M}),{ }^{10}$ panx1 $(100 \mu \mathrm{M})$ or probenecid $(500 \mu \mathrm{M})$ for $15 \mathrm{~min}$ before and during the Etd uptake.

\subsection{Dye Coupling}

Astrocytes plated on glass coverslips were iontophoretically microinjected with a glass micropipette filled with $75 \mathrm{mM}$ Etd in recording medium $\left(\mathrm{HCO}_{3}\right.$-free $\mathrm{F}-12$ medium buffered with $10 \mathrm{mM}$ HEPES, pH 7.2) containing $200 \mu \mathrm{M} \mathrm{La}^{3+}$. This blocker was used to prevent cell leakage of the microinjected Etd via hemichannels, which could underestimate the transfer of Etd to neighboring cells. Astrocytes were visualized through a Nikon inverted microscope equipped with epifluorescence illumination (Xenon arc lamp) and Nikon B filter to Etd (excitation wavelength $528 \mathrm{~nm}$; emission wavelength above $598 \mathrm{~nm}$ ) and XF34 filter to DiI fluorescence (Omega Optical, Inc., Brattleboro, VT, USA). Photomicrographs were captured employing a CCD monochrome camera (CFW-1310M; Scion; Frederick, MD, USA). Five minutes after dye injection, the coupling incidence was calculated as the percentage of injections that resulted in Etd transfer from the injected cell to more than one neighboring cell, whereas the coupling index was calculated as the mean number of cells to which the Etd spread. Etd coupling was tested by microinjecting a minimum of 10 cells per experiment.

\subsection{Immunofluorescence and Confocal Microscopy}

Astrocytes plated on glass coverslips were with 2\% paraformaldehyde (PFA) for 30 min fixed at room temperature. After washing three times with PBS, they were rinsed three times with ( 5 min each) 0.1 M PBS-glycine, and then incubated with $0.1 \%$ Triton X-100 in PBS containing 10\% NGS for 30 min. Then astrocytes were incubated with an anti-GFAP monoclonal antibody (BD Biosciences, 1:400) or anti-Cx43 polyclonal antibody (SIGMA, 1:400) diluted in $0.1 \%$ Triton X-100 in PBS with $2 \%$ NGS at $4{ }^{\circ} \mathrm{C}$ overnight. After five rinses in $0.1 \%$ Triton X-100 in PBS, cells were incubated with goat anti-mouse IgG Alexa Fluor 355 (1:1000) or goat anti-rabbit IgG Alexa Fluor 488 (1:1000) at room temperature for $50 \mathrm{~min}$. After washing, coverslips were mounted in DAKO fluorescent mounting medium and examined with an Olympus BX 51W1I upright microscope with a 40× water immersion. Nuclei were stained with DAPI or Hoechst 33342.

\section{8. $\left[\mathrm{Ca}^{2+}\right]_{i}$ and NO Imaging}

Astrocytes plated on glass coverslips were loaded with $5 \mu \mathrm{M}$ Fura-2-AM or $5 \mu \mathrm{M}$ DAF-FM in DMEM without serum at $37^{\circ} \mathrm{C}$ for $45 \mathrm{~min}$ and then washed three times in Locke's solution followed by de-esterification at $37^{\circ} \mathrm{C}$ for $15 \mathrm{~min}$. The experimental protocol for $\left[\mathrm{Ca}^{2+}\right]_{i}$ and nitric oxide (NO) imaging involved data acquisition every $5 \mathrm{~s}$ (emission at 510 and $515 \mathrm{~nm}$, respectively) at 340/380-nm and 495 excitation wavelengths, respectively, using the same microscope and acquisition mentioned 
above for Etd uptake. The FURA-2AM ratio was obtained after dividing the 340-nm by the 380-nm fluorescence image on a pixel-by-pixel base $\left(R=F_{340 ~ n m} / F_{380 ~ n m}\right)$.

\subsection{Measurement of IL-1 $\beta, T N F-\alpha$ and ATP Concentration}

Extracellular amounts of IL-1 $\beta$, TNF- $\alpha$ and ATP were measured in CM of astrocytes. Samples were centrifuged at $14.000 \times g$ for $40 \mathrm{~min}$ and then supernatants were collected and protein content analyzed through the bicinchoninic acid assay (BCA) technique. The amounts of IL-1 $\beta$ and TNF- $\alpha$ were determined by sandwich ELISA, as stated by the manufacturer (eBioscience, San Diego, CA, USA), whereas ATP levels were determined using a luciferin/luciferase bioluminescence assay kit (Sigma-Aldrich) as previously reported [44].

\subsection{Acute Brain Slices}

Coronal slices $(300 \mu \mathrm{m})$ from anesthetized mice with isoflurane were obtained using a vibratome (Leica, VT1000GS; Leica, Wetzlar, Germany) in ice-cold slicing solution containing (in mM): sucrose (222); $\mathrm{KCl}$ (2.6); $\mathrm{NaHCO}_{3}$ (27); $\mathrm{NaHPO}_{4}$ (1.5); glucose (10); $\mathrm{MgSO}_{4}$ (7); $\mathrm{CaCl}_{2}$ (0.5) and ascorbate (0.1), bubbled with $95 \% \mathrm{O}_{2} / 5 \% \mathrm{CO}_{2}$, $\mathrm{pH}$ 7.4. Then, the slices were transferred at room temperature $\left(20-22{ }^{\circ} \mathrm{C}\right)$ to a holding chamber in ice-cold artificial cerebral spinal fluid (ACSF) containing (in mM): $\mathrm{NaCl}$ (125), $\mathrm{KCl}$ (2.5), glucose (25), $\mathrm{NaHCO}_{3}$ (25), $\mathrm{NaH}_{2} \mathrm{PO}_{4}$ (1.25), $\mathrm{CaCl}_{2}$ (2) and $\mathrm{MgCl}_{2}$ (1), bubbled with $95 \%$ $\mathrm{O}_{2} / 5 \% \mathrm{CO}_{2}, \mathrm{pH} 7.4$, for a stabilization period of $60 \mathrm{~min}$ before dye uptake experiments.

\subsection{Dye Uptake in Acute Brain Slices and Confocal Microscopy}

Acute brain slices were incubated with $25 \mu \mathrm{M}$ Etd for $10 \mathrm{~min}$ in a chamber filled with ACSF and bubbled with $95 \% \mathrm{O}_{2} / 5 \% \mathrm{CO}_{2}$, $\mathrm{pH}$ 7.4. Afterward, the slices were washed three times (5 min each) with ACSF, and fixed at room temperature with $4 \%$ paraformaldehyde for $60 \mathrm{~min}$, rinsed once with $0.1 \mathrm{mM}$ glycine in phosphate-buffered saline (PBS) for $5 \mathrm{~min}$ and then twice with PBS for $10 \mathrm{~min}$ with gentle agitation. Then, the slices were incubated two times for $30 \mathrm{~min}$ each with a blocking solution (PBS, gelatin $0.2 \%$, Triton-X $1001 \%$ ) at room temperature. Further, the slices were incubated overnight at $4{ }^{\circ} \mathrm{C}$ with an anti-GFAP monoclonal antibody (1:500, SIGMA) to detect astrocytes. Later, the slices were washed three times (10 min each) with a blocking solution and then incubated for $2 \mathrm{~h}$ at room temperature with goat anti-mouse Alexa Fluor 488 (1:1000) antibody and Hoechst 33342. Afterward, the slices were washed three times (10 min each) in PBS and then mounted in Fluoromount, cover-slipped and examined in a confocal laser-scanning microscope (Eclipse Ti-E C2, Nikon, Japan). Stacks of consecutive confocal images were taken with $40 \times$ objective at $100 \mathrm{~nm}$ intervals were acquired sequentially with three lasers (in $\mathrm{nm}: 408,488$ and 543), and Z projections were reconstructed using Nikon confocal software (NIS-elements) and ImageJ software. Etd uptake was calculated with the same formula mentioned for cell cultures. At least six cells per field were selected from at least three fields in each brain slice.

\subsection{Data Analysis and Statistics}

For each data group, results were expressed as mean \pm standard error (SEM); $n$ refers to the number of independent experiments. Detailed statistical results were included in the figure legends. Statistical analyses were performed using GraphPad Prism (version 7, GraphPad Software, La Jolla, CA, USA). Normality and equal variances were assessed by the Shapiro-Wilk normality test and Brown-Forsythe test, respectively. Unless otherwise stated, data that passed these tests were analyzed by unpaired $t$-test in case of comparing two groups, whereas in case of multiple comparisons, data were analyzed by a one or two-way analysis of variance (ANOVA) followed, in the case of the significance, by a Tukey's post-hoc test. When data were heteroscedastic as well as not normal and with unequal variances, we used the Mann-Whitney test in the case of comparing two groups, whereas multiple comparisons data were analyzed by Kruskal-Wallis test followed, in the case of the significance, by a Dunn's post-hoc test. A probability of $p<0.05$ was considered statistically significant. 
Author Contributions: Conceptualization, J.A.O. and E.A.E.; Methodology, J.A.O. and R.G.-G.; Software, R.G.-G.; Validation, C.A.S., V.C.L. and G.I.G.; Formal Analysis, R.G.-G., C.A.S., V.C.L. and G.I.G.; Investigation, R.G.-G., C.A.S., V.C.L. and G.I.G.; Resources, J.A.O.; Data Curation, R.G.-G. and J.A.O.; Writing-Original Draft Preparation, J.A.O. and E.A.E.; Writing-Review and Editing, J.A.O. and E.A.E.; Visualization, J.A.O.; Supervision, J.A.O.; Project Administration, J.A.O. and V.C.L.; Funding Acquisition, J.A.O. All authors have read and approved the final version of the manuscript.

Funding: This research was funded by the Fondo Nacional de Desarrollo Científico y Tecnológico (FONDECYT) Grant 1160710 (to JAO), the Comisión Nacional de Investigación Científica y Tecnológica (CONICYT), Programa de Investigación Asociativa (PIA) Grant Anillo de Ciencia y Tecnología ACT1411 (to JAO), the National Institute of Mental Health grant, MH096625 (to EAE), the National Institute of Neurological Disorders and Stroke, NS105584 (to EAE), and UTMB internal funding (to EAE). The authors declare no conflict of interest. The data that support the findings of this study are available from the corresponding author upon reasonable request.

Conflicts of Interest: The authors declare no conflict of interest.

\section{Abbreviations}

$\begin{array}{ll}\text { BBB } & \text { Blood-brain barrier } \\ \text { CNS } & \text { Central nervous system } \\ \text { HAND } & \text { HIV-associated neurocognitive disorders } \\ \text { Cx43 } & \text { Connexin43 } \\ \text { Panx1 } & \text { Panx1 } \\ \text { NO } & \text { Nitric oxide } \\ \text { Etd } & \text { Ethidium } \\ \text { iNOS } & \text { Inducible NO synthase }\end{array}$

\section{References}

1. Resnick, L.; Berger, J.R.; Shapshak, P.; Tourtellotte, W.W. Early penetration of the blood-brain-barrier by HIV. Neurology 1988, 38, 9-14. [CrossRef]

2. Davis, L.E.; Hjelle, B.L.; Miller, V.E.; Palmer, D.L.; Llewellyn, A.L.; Merlin, T.L.; Young, S.A.; Mills, R.G.; Wachsman, W.; Wiley, C.A. Early viral brain invasion in iatrogenic human immunodeficiency virus infection. Neurology 1992, 42, 1736-1739. [CrossRef] [PubMed]

3. Lee, S.C.; Hatch, W.C.; Liu, W.; Kress, Y.; Lyman, W.D.; Dickson, D.W. Productive infection of human fetal microglia by HIV-1. Am. J. Pathol. 1993, 143, 1032-1039. [CrossRef] [PubMed]

4. Tornatore, C.; Meyers, K.; Atwood, W.; Conant, K.; Major, E. Temporal patterns of human immunodeficiency virus type 1 transcripts in human fetal astrocytes. J. Virol. 1994, 68, 93-102. [CrossRef] [PubMed]

5. Pandey, H.S.; Seth, P. Friends Turn Foe-Astrocytes Contribute to Neuronal Damage in NeuroAIDS. J. Mol. Neurosci. 2019, 69, 286-297. [CrossRef]

6. Mocchetti, I.; Campbell, L.A.; Harry, G.J.; Avdoshina, V. When human immunodeficiency virus meets chemokines and microglia: Neuroprotection or neurodegeneration? J. Neuroimmune Pharm. 2013, 8, 118-131. [CrossRef]

7. Gonzalez-Scarano, F.; Martin-Garcia, J. The neuropathogenesis of AIDS. Nat. Rev. Immunol. 2005, 5, 69-81. [CrossRef]

8. Kaul, M.; Zheng, J.; Okamoto, S.; Gendelman, H.E.; Lipton, S.A. HIV-1 infection and AIDS: Consequences for the central nervous system. Cell Death Differ. 2005, 12 (Suppl. 1), 878-892. [CrossRef]

9. McArthur, J.C.; Brew, B.J.; Nath, A. Neurological complications of HIV infection. Lancet Neurol. 2005, 4, 543-555. [CrossRef]

10. Spudich, S.; Gonzalez-Scarano, F. HIV-1-related central nervous system disease: Current issues in pathogenesis, diagnosis, and treatment. Cold Spring Harb Perspect Med. 2012, 2, a007120. [CrossRef]

11. Ellis, R.J.; Rosario, D.; Clifford, D.B.; McArthur, J.C.; Simpson, D.; Alexander, T.; Gelman, B.B.; Vaida, F.; Collier, A.; Marra, C.M.; et al. Continued high prevalence and adverse clinical impact of human immunodeficiency virus-associated sensory neuropathy in the era of combination antiretroviral therapy: The CHARTER Study. Arch. Neurol. 2010, 67, 552-558. [CrossRef]

12. Ellis, R.; Langford, D.; Masliah, E. HIV and antiretroviral therapy in the brain: Neuronal injury and repair. Nat. Rev. Neurosci. 2007, 8, 33-44. [CrossRef] 
13. Saylor, D.; Dickens, A.M.; Sacktor, N.; Haughey, N.; Slusher, B.; Pletnikov, M.; Mankowski, J.L.; Brown, A.; Volsky, D.J.; McArthur, J.C. HIV-associated neurocognitive disorder-pathogenesis and prospects for treatment. Nat. Rev. Neurol. 2016, 12, 234-248. [CrossRef]

14. Kerza-Kwiatecki, A.P.; Amini, S. CNS as an HIV-1 reservoir; BBB and drug delivery. J. Neurovirol. 1999, 5, 113-114. [CrossRef]

15. Weber, B.; Barros, L.F. The Astrocyte: Powerhouse and Recycling Center. Cold Spring Harb Perspect Biol. 2015, 7, a020396. [CrossRef]

16. Perea, G.; Navarrete, M.; Araque, A. Tripartite synapses: Astrocytes process and control synaptic information. Trends Neurosci. 2009, 32, 421-431. [CrossRef] [PubMed]

17. Bazargani, N.; Attwell, D. Astrocyte calcium signaling: The third wave. Nat. Neurosci. 2016, 19, $182-189$. [CrossRef] [PubMed]

18. Gundersen, V.; Storm-Mathisen, J.; Bergersen, L.H. Neuroglial Transmission. Physiol. Rev. 2015, 95, $695-726$. [CrossRef] [PubMed]

19. Viviani, B.; Corsini, E.; Binaglia, M.; Galli, C.L.; Marinovich, M. Reactive oxygen species generated by glia are responsible for neuron death induced by human immunodeficiency virus-glycoprotein 120 in vitro. Neuroscience 2001, 107, 51-58. [CrossRef]

20. Eugenin, E.A.; Berman, J.W. Gap junctions mediate human immunodeficiency virus-bystander killing in astrocytes. J. Neurosci. 2007, 27, 12844-12850. [CrossRef] [PubMed]

21. Patton, H.K.; Zhou, Z.H.; Bubien, J.K.; Benveniste, E.N.; Benos, D.J. gp120-induced alterations of human astrocyte function: $\mathrm{Na}(+) / \mathrm{H}(+)$ exchange, $\mathrm{K}(+)$ conductance, and glutamate flux. Am. J. Physiol. Cell Physiol. 2000, 279, C700-C708. [CrossRef] [PubMed]

22. Vesce, S.; Bezzi, P.; Rossi, D.; Meldolesi, J.; Volterra, A. HIV-1 gp120 glycoprotein affects the astrocyte control of extracellular glutamate by both inhibiting the uptake and stimulating the release of the amino acid. Febs Lett. 1997, 411, 107-109. [CrossRef]

23. Holden, C.P.; Haughey, N.J.; Nath, A.; Geiger, J.D. Role of Na+/H+ exchangers, excitatory amino acid receptors and voltage-operated $\mathrm{Ca} 2+$ channels in human immunodeficiency virus type 1 gp120-mediated increases in intracellular Ca2+ in human neurons and astrocytes. Neuroscience 1999, 91, 1369-1378. [CrossRef]

24. Shah, A.; Kumar, A. HIV-1 gp120-mediated increases in IL-8 production in astrocytes are mediated through the NF-kappaB pathway and can be silenced by gp120-specific siRNA. J. Neuroinflamm. 2010, 7, 96. [CrossRef] [PubMed]

25. Shah, A.; Singh, D.P.; Buch, S.; Kumar, A. HIV-1 envelope protein gp120 up regulates CCL5 production in astrocytes which can be circumvented by inhibitors of NF-kappaB pathway. Biochem. Biophys. Res. Commun. 2011, 414, 112-117. [CrossRef] [PubMed]

26. Ronaldson, P.T.; Bendayan, R. HIV-1 viral envelope glycoprotein gp120 produces oxidative stress and regulates the functional expression of multidrug resistance protein-1 (Mrp1) in glial cells. J. Neurochem. 2008, 106, 1298-1313. [CrossRef] [PubMed]

27. Orellana, J.A.; Retamal, M.A.; Moraga-Amaro, R.; Stehberg, J. Role of Astroglial Hemichannels and Pannexons in Memory and Neurodegenerative Diseases. Front. Integr. Neurosci. 2016, 10, 26. [CrossRef]

28. Saez, J.C.; Leybaert, L. Hunting for connexin hemichannels. Febs Lett. 2014, 588, 1205-1211. [CrossRef]

29. Bond, S.R.; Naus, C.C. The pannexins: Past and present. Front. Physiol. 2014, 5, 58. [CrossRef]

30. Retamal, M.A.; Reyes, E.P.; Garcia, I.E.; Pinto, B.; Martinez, A.D.; Gonzalez, C. Diseases associated with leaky hemichannels. Front. Cell Neurosci. 2015, 9, 267. [CrossRef]

31. Penuela, S.; Harland, L.; Simek, J.; Laird, D.W. Pannexin channels and their links to human disease. Biochem. J. 2014, 461, 371-381. [CrossRef]

32. Orellana, J.A.; Saez, J.C.; Bennett, M.V.; Berman, J.W.; Morgello, S.; Eugenin, E.A. HIV increases the release of dickkopf-1 protein from human astrocytes by a Cx43 hemichannel-dependent mechanism. J. Neurochem. 2014, 128, 752-763. [CrossRef]

33. Johnson, R.G.; Le, H.C.; Evenson, K.; Loberg, S.W.; Myslajek, T.M.; Prabhu, A.; Manley, A.M.; O'Shea, C.; Grunenwald, H.; Haddican, M.; et al. Connexin Hemichannels: Methods for Dye Uptake and Leakage. J. Membr. Biol. 2016, 249, 713-741. [CrossRef] 
34. Contreras, J.E.; Sanchez,H.A.; Eugenin, E.A.; Speidel, D.; Theis, M.; Willecke, K.; Bukauskas, F.F.; Bennett, M.V.; Saez, J.C. Metabolic inhibition induces opening of unapposed connexin 43 gap junction hemichannels and reduces gap junctional communication in cortical astrocytes in culture. Proc. Natl. Acad. Sci. USA 2002, 99, 495-500. [CrossRef] [PubMed]

35. Iglesias, R.; Dahl, G.; Qiu, F.; Spray, D.C.; Scemes, E. Pannexin 1: The molecular substrate of astrocyte "hemichannels". J. Neurosci. 2009, 29, 7092-7097. [CrossRef] [PubMed]

36. Ponsaerts, R.; De Vuyst, E.; Retamal, M.; D’Hondt, C.; Vermeire, D.; Wang, N.; De Smedt, H.; Zimmermann, P.; Himpens, B.; Vereecke, J.; et al. Intramolecular loop/tail interactions are essential for connexin 43-hemichannel activity. FASEB J. 2010, 24, 4378-4395. [CrossRef] [PubMed]

37. Wang, N.; De Vuyst, E.; Ponsaerts, R.; Boengler, K.; Palacios-Prado, N.; Wauman, J.; Lai, C.P.; De Bock, M.; Decrock, E.; Bol, M.; et al. Selective inhibition of Cx43 hemichannels by Gap19 and its impact on myocardial ischemia/reperfusion injury. Basic Res. Cardiol. 2013, 108, 309. [CrossRef]

38. Abudara, V.; Bechberger, J.; Freitas-Andrade, M.; De Bock, M.; Wang, N.; Bultynck, G.; Naus, C.C.; Leybaert, L.; Giaume, C. The connexin43 mimetic peptide Gap19 inhibits hemichannels without altering gap junctional communication in astrocytes. Front. Cell Neurosci. 2014, 8, 306. [CrossRef]

39. Pelegrin, P.; Surprenant, A. Pannexin-1 mediates large pore formation and interleukin-1beta release by the ATP-gated P2X7 receptor. Embo J. 2006, 25, 5071-5082. [CrossRef] [PubMed]

40. Silverman, W.; Locovei, S.; Dahl, G. Probenecid, a gout remedy, inhibits pannexin 1 channels. Am. J. Physiol. Cell Physiol. 2008, 295, C761-C767. [CrossRef]

41. Retamal, M.A.; Froger, N.; Palacios-Prado, N.; Ezan, P.; Saez, P.J.; Saez, J.C.; Giaume, C. Cx43 hemichannels and gap junction channels in astrocytes are regulated oppositely by proinflammatory cytokines released from activated microglia. J. Neurosci. 2007, 27, 13781-13792. [CrossRef] [PubMed]

42. De Bock, M.; Wang, N.; Bol, M.; Decrock, E.; Ponsaerts, R.; Bultynck, G.; Dupont, G.; Leybaert, L. Connexin 43 hemichannels contribute to cytoplasmic $\mathrm{Ca} 2+$ oscillations by providing a bimodal Ca2+-dependent $\mathrm{Ca} 2+$ entry pathway. J. Biol. Chem. 2012, 287, 12250-12266. [CrossRef] [PubMed]

43. Gajardo-Gomez, R.; Labra, V.C.; Maturana, C.J.; Shoji, K.F.; Santibanez, C.A.; Saez, J.C.; Giaume, C.; Orellana, J.A. Cannabinoids prevent the amyloid beta-induced activation of astroglial hemichannels: A neuroprotective mechanism. Glia 2017, 65, 122-137. [CrossRef]

44. Diaz, E.F.; Labra, V.C.; Alvear, T.F.; Mellado, L.A.; Inostroza, C.A.; Oyarzun, J.E.; Salgado, N.; Quintanilla, R.A.; Orellana, J.A. Connexin 43 hemichannels and pannexin-1 channels contribute to the alpha-synuclein-induced dysfunction and death of astrocytes. Glia 2019, 67, 1598-1619.

45. Locovei, S.; Wang, J.; Dahl, G. Activation of pannexin 1 channels by ATP through P2Y receptors and by cytoplasmic calcium. FEBS Lett. 2006, 580, 239-244. [CrossRef]

46. Baroja-Mazo, A.; Barbera-Cremades, M.; Pelegrin, P. The participation of plasma membrane hemichannels to purinergic signaling. Biochem. Biophys. Acta 2013, 1828, 79-93. [CrossRef]

47. Giaume, C.; Koulakoff, A.; Roux, L.; Holcman, D.; Rouach, N. Astroglial networks: A step further in neuroglial and gliovascular interactions. Nat. Rev. Neurosci. 2010, 11, 87-99. [CrossRef]

48. Rodrigues, R.J.; Tome, A.R.; Cunha, R.A. ATP as a multi-target danger signal in the brain. Front. Neurosci. 2015, 9, 148. [CrossRef]

49. Kang, J.; Kang, N.; Lovatt, D.; Torres, A.; Zhao, Z.; Lin, J.; Nedergaard, M. Connexin 43 hemichannels are permeable to ATP. J. Neurosci. 2008, 28, 4702-4711. [CrossRef]

50. Pekny, M.; Pekna, M. Astrocyte reactivity and reactive astrogliosis: Costs and benefits. Physiol Rev. 2014, 94, 1077-1098. [CrossRef]

51. Abudara, V.; Roux, L.; Dallerac, G.; Matias, I.; Dulong, J.; Mothet, J.P.; Rouach, N.; Giaume, C. Activated microglia impairs neuroglial interaction by opening Cx43 hemichannels in hippocampal astrocytes. Glia 2015, 63, 795-811. [CrossRef] [PubMed]

52. Parzych, K.; Zetterqvist, A.V.; Wright, W.R.; Kirkby, N.S.; Mitchell, J.A.; Paul-Clark, M.J. Differential role of pannexin-1/ATP/P2X7 axis in IL-1beta release by human monocytes. Faseb J. 2017, 31, 2439-2445. [CrossRef] [PubMed]

53. Mugisho, O.O.; Green, C.R.; Kho, D.T.; Zhang, J.; Graham, E.S.; Acosta, M.L.; Rupenthal, I.D. The inflammasome pathway is amplified and perpetuated in an autocrine manner through connexin43 hemichannel mediated ATP release. Biochim. Et Biophys. Acta. Gen. Subj. 2018, 1862, 385-393. [CrossRef] [PubMed] 
54. Wei, L.; Sheng, H.; Chen, L.; Hao, B.; Shi, X.; Chen, Y. Effect of pannexin-1 on the release of glutamate and cytokines in astrocytes. J. Clin. Neurosci. 2016, 23, 135-141. [CrossRef] [PubMed]

55. Agulhon, C.; Sun, M.Y.; Murphy, T.; Myers, T.; Lauderdale, K.; Fiacco, T.A. Calcium Signaling and Gliotransmission in Normal vs. Reactive Astrocytes. Front. Pharm. 2012, 3, 139. [CrossRef] [PubMed]

56. Schalper, K.A.; Sanchez, H.A.; Lee, S.C.; Altenberg, G.A.; Nathanson, M.H.; Saez, J.C. Connexin 43 hemichannels mediate the Ca2+ influx induced by extracellular alkalinization. Am. J. Physiol. Cell Physiol. 2010, 299, C1504-C1515. [CrossRef]

57. Meunier, C.; Wang, N.; Yi, C.; Dallerac, G.; Ezan, P.; Koulakoff, A.; Leybaert, L.; Giaume, C. Contribution of Astroglial Cx43 Hemichannels to the Modulation of Glutamatergic Currents by D-Serine in the Mouse Prefrontal Cortex. J. Neurosci. 2017, 37, 9064-9075. [CrossRef]

58. Ishikawa, M.; Iwamoto, T.; Nakamura, T.; Doyle, A.; Fukumoto, S.; Yamada, Y. Pannexin 3 functions as an ER $\mathrm{Ca}(2+)$ channel, hemichannel, and gap junction to promote osteoblast differentiation. J. Cell Biol. 2011, 193, 1257-1274. [CrossRef]

59. Fiori, M.C.; Figueroa, V.; Zoghbi, M.E.; Saez, J.C.; Reuss, L.; Altenberg, G.A. Permeation of calcium through purified connexin 26 hemichannels. J. Biol. Chem. 2012, 287, 40826-40834. [CrossRef]

60. Garre, J.M.; Yang, G.; Bukauskas, F.F.; Bennett, M.V. FGF-1 Triggers Pannexin-1 Hemichannel Opening in Spinal Astrocytes of Rodents and Promotes Inflammatory Responses in Acute Spinal Cord Slices. J. Neurosci. 2016, 36, 4785-4801. [CrossRef]

61. Gomez, G.I.; Falcon, R.V.; Maturana, C.J.; Labra, V.C.; Salgado, N.; Rojas, C.A.; Oyarzun, J.E.; Cerpa, W.; Quintanilla, R.A.; Orellana, J.A. Heavy Alcohol Exposure Activates Astroglial Hemichannels and Pannexons in the Hippocampus of Adolescent Rats: Effects on Neuroinflammation and Astrocyte Arborization. Front. Cell Neurosci. 2018, 12, 472. [CrossRef]

62. Wei, H.; Deng, F.; Chen, Y.; Qin, Y.; Hao, Y.; Guo, X. Ultrafine carbon black induces glutamate and ATP release by activating connexin and pannexin hemichannels in cultured astrocytes. Toxicology 2014, 323, $32-41$. [CrossRef] [PubMed]

63. Yi, C.; Mei, X.; Ezan, P.; Mato, S.; Matias, I.; Giaume, C.; Koulakoff, A. Astroglial connexin 43 contributes to neuronal suffering in a mouse model of Alzheimer's disease. Cell Death Differ. 2016, 23, 1691-1701. [CrossRef] [PubMed]

64. Garre, J.M.; Retamal, M.A.; Cassina, P.; Barbeito, L.; Bukauskas, F.F.; Saez, J.C.; Bennett, M.V.; Abudara, V. FGF-1 induces ATP release from spinal astrocytes in culture and opens pannexin and connexin hemichannels. Proc. Natl. Acad. Sci. USA 2010, 107, 22659-22664. [CrossRef] [PubMed]

65. Karpuk, N.; Burkovetskaya, M.; Fritz, T.; Angle, A.; Kielian, T. Neuroinflammation leads to region-dependent alterations in astrocyte gap junction communication and hemichannel activity. J. Neurosci. 2011, 31, 414-425. [CrossRef] [PubMed]

66. Orellana, J.A.; Hernandez, D.E.; Ezan, P.; Velarde, V.; Bennett, M.V.; Giaume, C.; Saez, J.C. Hypoxia in high glucose followed by reoxygenation in normal glucose reduces the viability of cortical astrocytes through increased permeability of connexin 43 hemichannels. Glia 2010, 58, 329-343. [CrossRef]

67. Lin, J.H.; Weigel, H.; Cotrina, M.L.; Liu, S.; Bueno, E.; Hansen, A.J.; Hansen, T.W.; Goldman, S.; Nedergaard, M. Gap-junction-mediated propagation and amplification of cell injury. Nat. Neurosci. 1998, 1, 494-500. [CrossRef]

68. Andrade-Rozental, A.F.; Rozental, R.; Hopperstad, M.G.; Wu, J.K.; Vrionis, F.D.; Spray, D.C. Gap junctions: The "kiss of death" and the "kiss of life". Brain Res. Brain Res. Rev. 2000, 32, 308-315. [CrossRef]

69. Spray, D.C.; Hanstein, R.; Lopez-Quintero, S.V.; Stout, R.F., Jr.; Suadicani, S.O.; Thi, M.M. Gap junctions and Bystander Effects: Good Samaritans and executioners. Wiley Interdiscip Rev. Membr Transp Signal. 2013, 2, 1-15. [CrossRef]

70. Decrock, E.; Krysko, D.V.; Vinken, M.; Kaczmarek, A.; Crispino, G.; Bol, M.; Wang, N.; De Bock, M.; De Vuyst, E.; Naus, C.C.; et al. Transfer of IP(3) through gap junctions is critical, but not sufficient, for the spread of apoptosis. Cell Death Differ. 2012, 19, 947-957. [CrossRef]

71. Persichini, T.; Mastrantonio, R.; Del Matto, S.; Palomba, L.; Cantoni, O.; Colasanti, M. The role of arachidonic acid in the regulation of nitric oxide synthase isoforms by HIV gp120 protein in astroglial cells. Free Radic Biol. Med. 2014, 74, 14-20. [CrossRef] [PubMed] 
72. Ronaldson, P.T.; Bendayan, R. HIV-1 viral envelope glycoprotein gp120 triggers an inflammatory response in cultured rat astrocytes and regulates the functional expression of P-glycoprotein. Mol. Pharm. 2006, 70, 1087-1098. [CrossRef] [PubMed]

73. Sippy, B.D.; Hofman, F.M.; Wallach, D.; Hinton, D.R. Increased expression of tumor necrosis factor-alpha receptors in the brains of patients with AIDS. J. Acquir. Immune Defic. Syndr. Hum. Retrovirol. 1995, 10, 511-521. [CrossRef] [PubMed]

74. Avendano, B.C.; Montero, T.D.; Chavez, C.E.; von Bernhardi, R.; Orellana, J.A. Prenatal exposure to inflammatory conditions increases $\mathrm{C} \times 43$ and Panx1 unopposed channel opening and activation of astrocytes in the offspring effect on neuronal survival. Glia 2015, 63, 2058-2072. [CrossRef]

75. Abdalla, F.; Nookala, A.; Padhye, S.B.; Kumar, A.; Bhat, H.K. 4-(E)-\{(p-tolylimino)-methylbenzene-1,2-diol\} (TIMBD) suppresses HIV1-gp120 mediated production of IL6 and IL8 but not CCL5. Sci Rep. 2017, 7, 8129. [CrossRef]

76. Da Silva, J.; Pierrat, B.; Mary, J.L.; Lesslauer, W. Blockade of p38 mitogen-activated protein kinase pathway inhibits inducible nitric-oxide synthase expression in mouse astrocytes. J. Biol. Chem. 1997, 272, 28373-28380. [CrossRef]

77. Ding, M.; St Pierre, B.A.; Parkinson, J.F.; Medberry, P.; Wong, J.L.; Rogers, N.E.; Ignarro, L.J.; Merrill, J.E. Inducible nitric-oxide synthase and nitric oxide production in human fetal astrocytes and microglia. A kinetic analysis. J. Biol. Chem. 1997, 272, 11327-11335. [CrossRef]

78. Bartus, K.; Pigott, B.; Garthwaite, J. Cellular targets of nitric oxide in the hippocampus. PLoS ONE 2013, 8, e57292. [CrossRef]

79. Wang, L.; Hagemann, T.L.; Kalwa, H.; Michel, T.; Messing, A.; Feany, M.B. Nitric oxide mediates glial-induced neurodegeneration in Alexander disease. Nat. Commun 2015, 6, 8966. [CrossRef]

80. Orellana, J.A.; Montero, T.D.; von Bernhardi, R. Astrocytes inhibit nitric oxide-dependent Ca(2+) dynamics in activated microglia: Involvement of ATP released via pannexin 1 channels. Glia 2013, 61, 2023-2037. [CrossRef]

81. Datta, G.; Miller, N.M.; Afghah, Z.; Geiger, J.D.; Chen, X. HIV-1 gp120 Promotes Lysosomal Exocytosis in Human Schwann Cells. Front. Cell Neurosci. 2019, 13, 329. [CrossRef] [PubMed]

82. Velasquez, S.; Prevedel, L.; Valdebenito, S.; Gorska, A.M.; Golovko, M.; Khan, N.; Geiger, J.; Eugenin, E.A. Circulating levels of ATP is a biomarker of HIV cognitive impairment. EBioMedicine 2020, 51, 102503. [CrossRef] [PubMed]

83. Orellana, J.A.; Busso, D.; Ramirez, G.; Campos, M.; Rigotti, A.; Eugenin, J.; von Bernhardi, R. Prenatal nicotine exposure enhances Cx43 and Panx1 unopposed channel activity in brain cells of adult offspring mice fed a high-fat/cholesterol diet. Front. Cell Neurosci. 2014, 8, 403. [CrossRef] [PubMed]

84. Codazzi, F.; Menegon, A.; Zacchetti, D.; Ciardo, A.; Grohovaz, F.; Meldolesi, J. HIV-1 gp120 glycoprotein induces $[\mathrm{Ca} 2+]$ i responses not only in type-2 but also type-1 astrocytes and oligodendrocytes of the rat cerebellum. Eur. J. Neurosci. 1995, 7, 1333-1341. [CrossRef] [PubMed]

85. Chen, Q.; Wu, H.; Tao, J.; Liu, C.; Deng, Z.; Liu, Y.; Chen, G.; Liu, B.; Xu, C. Effect of naringin on gp120-induced injury mediated by P2X7 receptors in rat primary cultured microglia. PLoS ONE 2017, 12, e0183688. [CrossRef]

86. Hazleton, J.E.; Berman, J.W.; Eugenin, E.A. Purinergic receptors are required for HIV-1 infection of primary human macrophages. J. Immunol 2012, 188, 4488-4495. [CrossRef]

87. Vanden Abeele, F.; Bidaux, G.; Gordienko, D.; Beck, B.; Panchin, Y.V.; Baranova, A.V.; Ivanov, D.V.; Skryma, R.; Prevarskaya, N. Functional implications of calcium permeability of the channel formed by pannexin 1. J. Cell Biol. 2006, 174, 535-546. [CrossRef]

88. Neary, J.T.; Laskey, R.; van Breemen, C.; Blicharska, J.; Norenberg, L.O.; Norenberg, M.D. ATP-evoked calcium signal stimulates protein phosphorylation/dephosphorylation in astrocytes. Brain Res. 1991, 566, 89-94. [CrossRef]

89. Qiu, F.; Dahl, G. A permeant regulating its permeation pore: Inhibition of pannexin 1 channels by ATP. Am. J. Physiol. Cell Physiol. 2009, 296, C250-C255. [CrossRef]

90. Falzoni, S.; Donvito, G.; Di Virgilio, F. Detecting adenosine triphosphate in the pericellular space. Interface Focus 2013, 3, 20120101. [CrossRef]

91. Khakh, B.S.; Sofroniew, M.V. Diversity of astrocyte functions and phenotypes in neural circuits. Nat. Neurosci. 2015, 18, 942-952. [CrossRef] [PubMed] 
92. Houades, V.; Rouach, N.; Ezan, P.; Kirchhoff, F.; Koulakoff, A.; Giaume, C. Shapes of astrocyte networks in the juvenile brain. Neuron Glia Biol. 2006, 2, 3-14. [CrossRef] [PubMed]

93. Jinno, S. Regional and laminar differences in antigen profiles and spatial distributions of astrocytes in the mouse hippocampus, with reference to aging. Neuroscience 2011, 180, 41-52. [CrossRef] [PubMed]

94. Ben Haim, L.; Rowitch, D.H. Functional diversity of astrocytes in neural circuit regulation. Nat. Rev. Neurosci. 2017, 18, 31-41. [CrossRef]

95. D'Ambrosio, R.; Wenzel, J.; Schwartzkroin, P.A.; McKhann, G.M., 2nd; Janigro, D. Functional specialization and topographic segregation of hippocampal astrocytes. J. Neurosci. 1998, 18, 4425-4438. [CrossRef]

(C) 2020 by the authors. Licensee MDPI, Basel, Switzerland. This article is an open access article distributed under the terms and conditions of the Creative Commons Attribution (CC BY) license (http://creativecommons.org/licenses/by/4.0/). 